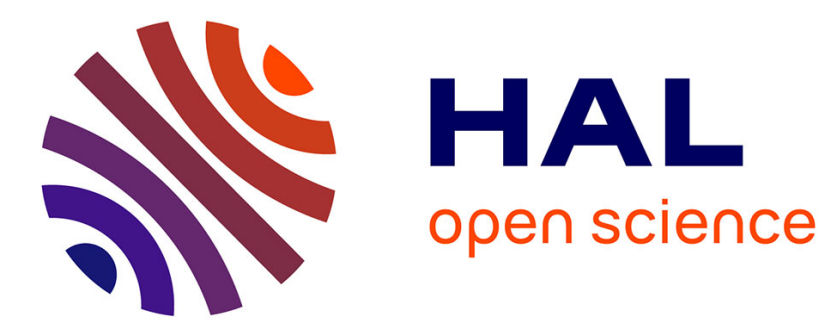

\title{
The aorist in Modern Armenian: core value and contextual meanings
}

Anaid Donabedian-Demopoulos

\section{To cite this version:}

Anaid Donabedian-Demopoulos. The aorist in Modern Armenian: core value and contextual meanings. Zlatka Guentcheva. Aspectuality and Temporality. Descriptive and theoretical issues, John Benjamins, pp.375 - 412, 2016, 9789027267610. 10.1075/slcs.172.12don . halshs-01424956

\section{HAL Id: halshs-01424956 \\ https://shs.hal.science/halshs-01424956}

Submitted on 6 Jan 2017

HAL is a multi-disciplinary open access archive for the deposit and dissemination of scientific research documents, whether they are published or not. The documents may come from teaching and research institutions in France or abroad, or from public or private research centers.
L'archive ouverte pluridisciplinaire HAL, est destinée au dépôt et à la diffusion de documents scientifiques de niveau recherche, publiés ou non, émanant des établissements d'enseignement et de recherche français ou étrangers, des laboratoires publics ou privés. 
The Aorist in Modern Armenian: core value and contextual meanings, in Guentchéva, Zlatka (ed.), Aspectuality and Temporality. Descriptive and theoretical issues, John Benjamins, 2016, p. 375-411 (the published paper miss examples written in Armenian)

\title{
The aorist in Modern Armenian: core values and contextual meanings
}

\author{
Anaïd Donabédian \\ (SeDyL, INALCO/USPC, CNRS UMR8202, IRD UMR135)
}

\section{Introduction}

Comparison between particular markers in different languages is always controversial, nevertheless linguists can identify in numerous languages a verb tense that can be described as aorist. Cross-linguistic differences exist, due to the diachrony of the markers in question and their position within the verbal system of a given language, but there are clearly a certain number of shared morphological, syntactic, semantic and/or pragmatic features.

The term "aorist”, of Greek origin, has been commonly applied to IndoEuropean languages on the basis of a common proto-form, which has been the subject of many studies of comparative grammar since the founding of the Indo-European linguistic tradition, and continues to be the object of much interest. But the aorist has also been conceptualized as a category of tenseaspect that need not be associated with any particular verb form, by writers from Aristotle to Culioli. This has led to the application of the "aorist" label to verb tenses in unrelated languages, ranging from Turkish, where it has become part of grammatical tradition, to Wolof, where its presence was suggested by Stéphane Robert (1996), even if in neither case do the semantic properties of the tense in question carry the past perfective meaning that is considered central for aorist by Indo-Europeanists and for some typologists, since Dahl 1985. Other shared features of tenses characterized as aorist include:

- formally speaking, a quite minimal morphology, sometimes even the bare root of the verb (as in Persian: kard 'to make', $c f$. Lazard 1957), but in no case a periphrastic form. In Hindi, for example, aorist and counterfactual are the only synthetic tenses in the verbal system, $c f$. Montaut (2006a). Interestingly, 
the tense called aorist by (Robert 1996) has been previously labeled "the zero aspect” by his predecessor, Sauvageot (1965: 102).

- a lack of anchoring in the moment of speech (cf. Culioli 1980), ${ }^{1}$ or of situational anchoring ( $c f$. Robert 1996). It will be shown here that in utterances in the aorist, the situational anchoring is carried not by the verb, but by the context (narration, circumstantials, etc.). Otherwise, the event is without temporal anchoring (gnomic and hypothetical utterances, for example). It follows from this that the aorist can be characterized by a more flexible temporal meaning than other past tenses, being able to carry apparently contradictory meanings (past and future, for example).

In a certain number of languages (notably Indo-European languages, such as Persian, Bulgarian, Greek, and even French -if we adopt Benveniste's view of the passé simple), what is called aorist tense embodies both what we call preterit uses (in the sense of non-periphrastic past perfective, corresponding to Dahl's definition of aorist) and aoristic uses. This is also the case of Modern Armenian.

This article aims to sketch the Tense-Aspect-Mood contours of the aorist in Modern Armenian. We will consider both its etymology and its morphology, as well as its uses and their semantic variation as observed synchronically, including the parameters of this variation. The Armenian aorist will be compared to that of other modern languages, in order to show both the ways in which it is emblematic of the category, and the ways in which it is idiosyncratic. By comparing Eastern and Western Armenian it will be possible to identify the influence of dialectical variation, as well as that of language contact.

The approach, inspired by Culioli's Théorie des operations énonciatives (see for example Culioli 1990), is particularly well-suited to show how the aorist functions. By placing the enunciation at the center of the grammatical analysis, this approach allows us to see how the same referential context can be expressed by different grammatical forms, depending on the situation of

1 «L'aoristique est défini par l'opération de repérage $\operatorname{Sit}_{0}\left(S_{n}, T_{n}\right) \omega \operatorname{Sit}_{m}, T_{m}$ où Sit ${ }_{m}$ (le repère) et $\mathrm{Sit}_{\mathrm{n}}$ (le repéré) sont deux occurrences distinctes de Sit, quel que soit, pour le problème considéré, le statut de $\mathrm{Sit}_{\mathrm{m}}, \mathrm{Sit}_{\mathrm{n}}$ ». A. Culioli (1980: 191) (The aoristic is defined by the anchoring operation $\operatorname{Sit}_{0}\left(S_{n}, T_{n}\right) \omega$ Sit $_{m}, T_{m}$ where Sit $t_{m}$ (the point of anchoring) and $\mathrm{Sit}_{n}$ (anchoree) are two different occurrences of Sit, whatever may be, for the problem in question, the status of $\mathrm{Sit}_{m}$, Sit $\mathrm{t}_{n}$ ).

"La relation $\omega$ est la relation de rupture: “ni identique ni différent” » (1980: 183) (The relationship $\omega$ is the relationship of rupture : "not identical, nor different")

«L'aoristique est une catégorie dont les marqueurs peuvent être le passé simple, l'imparfait, le passé composé, le présent, le futur, pour s'en tenir à ces exemples » (1980: 191) (The aoristic is a category that can be formally marked by the past simple, the imperfect, the passé composé, the present, the future, taking these examples into account only.). See also (Vogüé 1995). 
utterance and the speaker's attitudinal choices. In this approach, grammatical markers are taken as operators, and not as "encoders", and operators are defined by their own value rather than by systematic rules of use, which are sometimes observed, but inevitably come with a lot of counterexamples. This will shed light on the patterns these rules are trying to describe, but also on their inability to capture the full picture of the category.

\section{Lessons drawn from the place of the Aorist in the Armenian verbal system}

A simple observation of the Armenian verbal system, whether Old Armenian, Eastern or Western Modern Armenian, ${ }^{2}$ reveals that the aorist occupies a very specific and asymmetrical position in relation to each of the parameters of the morphological structure, shown below for the verb utem, "to eat", in both modern standards:

2 Both are modern languages, standardized in the 19th century, and having fathered an abundant literary tradition. Eastern Armenian (EMA) is the official language of the Republic of Armenia, and also the language of the Armenian community in Iran. Western Armenian (WMA), formerly spoken and taught in the Ottoman Empire, is the language of the western diaspora, and a vernacular and school language in the Middle East (especially in Syria and Lebanon). EMA and WMA have lexical, phonetic, morphologic and syntactic divergences. This paper discusses both variants, since they are very similar regarding the aorist, except in some uses that will be detailed here. By default, generalizations drawn here concern both modern standards. By default, examples are drawn from the Eastern National Armenian Corpus. WMA examples will be tagged as such. WMA did not apply the orthographical reform adopted in Soviet Armenia. The transcription adopted here, based on the written form, is adapted from the Hübschmann-Meiller-Benveniste scientific transliteration, and does not reflect orthographic features kept by WMA. Given consonant mutations that occured in WMA without graphic changes, transliteration is inevitably quite far from phonetics, for Armenian words as well as for foreigner words, written in Armenian. However, this choice was made to allow for the reflection of parallels between EMA and WMA.

3 Imperfective and Perfective stems are generally marked by a suffix $-\varnothing-/-c^{`}-$. but they can also be suppletive, as in the case of utem (root alternation ut-/ker-), chosen here for clarity. 


\begin{tabular}{|c|c|c|c|}
\hline Stem & Tense & Affirmative & Negative \\
\hline \multirow{4}{*}{ 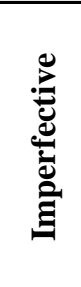 } & imperative sg & ker! & mi! uter \\
\hline & $\begin{array}{l}\text { subjunctive present } \\
\text { subjunctive imperfect }\end{array}$ & $\begin{array}{l}\text { ute-m } \\
\text { ute-i }\end{array}$ & $\begin{array}{l}\breve{c}^{\prime} \text {-ute-m } \\
\check{c}^{\prime} \text {-ute-i }\end{array}$ \\
\hline & $\begin{array}{l}\text { present } \\
\text { imperfect }\end{array}$ & $\begin{array}{l}k^{\prime} \text { ute-m } \\
k^{\prime} \text { ute-i }\end{array}$ & $\begin{array}{l}\check{c}^{-}-e m \text { ut-er } \\
\check{c} \text {-ei ut-er }\end{array}$ \\
\hline & $\begin{array}{l}\text { future } \\
\text { future in the past }\end{array}$ & $\begin{array}{l}\text { piti ute-m } \\
\text { piti ute-i }\end{array}$ & $\begin{array}{l}\text { piti } \check{c}^{-}-\text {-ute-m } \\
\text { piti } \check{c}^{-}-\text {-ute-i }\end{array}$ \\
\hline \multirow{3}{*}{ 胥 } & aorist & ker`-a & $\breve{c}-k e r-a$ \\
\hline & $\begin{array}{l}\text { present perfect } 1 \\
\text { pluperfect } 1\end{array}$ & $\begin{array}{l}\text { ker-ac em } \\
\text { ker-ac êi }\end{array}$ & $\begin{array}{l}\check{c}^{\prime} \text {-em kerac } \\
\check{c} \text { '-ei kerac }\end{array}$ \\
\hline & $\begin{array}{l}\text { present perfect } 2 \\
\text { pluperfect } 2\end{array}$ & $\begin{array}{l}\text { ker-er em } \\
\text { ker-er êi }\end{array}$ & $\begin{array}{l}\check{c} \text {-em kerer } \\
\check{c} \text {-ei kerer }\end{array}$ \\
\hline
\end{tabular}

Table 1: Synopsis of the Western Armenian verbal system

\begin{tabular}{|c|c|c|c|}
\hline Stem & Tense & Affirmative & Negative \\
\hline \multirow{6}{*}{ 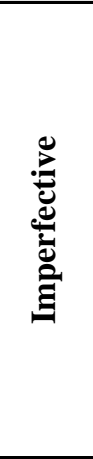 } & imperative sg & ker! & mi! ker \\
\hline & $\begin{array}{l}\text { subjunctive present } \\
\text { subjunctive imperfect }\end{array}$ & $\begin{array}{l}\text { ute-m } \\
\text { ute-i }\end{array}$ & $\begin{array}{l}\check{c}^{\prime}-\text { ute-m } \\
\check{c}^{\prime}-\text {-ute-i }\end{array}$ \\
\hline & $\begin{array}{l}\text { present } \\
\text { imperfect }\end{array}$ & $\begin{array}{l}\text { utum em } \\
\text { utum ei }\end{array}$ & $\begin{array}{l}\check{c} \text {-em utum } \\
\check{c} \text { '-ei utum }\end{array}$ \\
\hline & $\begin{array}{l}\text { future } 1 \\
\text { future in the past } 1\end{array}$ & $\begin{array}{l}\text { utelu em } \\
\text { utelu ei }\end{array}$ & $\begin{array}{l}\text { utelu } \check{c}^{`}-e m \\
\text { utelu } \check{c}^{-}-e i\end{array}$ \\
\hline & $\begin{array}{l}\text { future } 2 \\
\text { future in the past } 2\end{array}$ & $\begin{array}{l}\text { piti ute-m } \\
\text { piti ute-i }\end{array}$ & $\begin{array}{l}\check{c}^{\prime} \text {-piti ute-m } \\
\check{c}^{-} \text {-piti ute-i }\end{array}$ \\
\hline & $\begin{array}{l}\text { future } 3 \\
\text { conditional }\end{array}$ & $\begin{array}{l}k \text {-ute-m } \\
k \text {-ute-i }\end{array}$ & 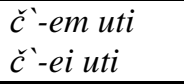 \\
\hline \multirow{2}{*}{ 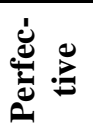 } & aorist & ker-a & $\check{c}^{`}$-ker-a \\
\hline & $\begin{array}{l}\text { present perfect } \\
\text { pluperfect }\end{array}$ & $\begin{array}{l}\text { kerel em } \\
\text { kerel ei }\end{array}$ & $\begin{array}{l}\text { čem kerel } \\
\text { čei kerel }\end{array}$ \\
\hline
\end{tabular}

Table 2: Synopsis of the Eastern Armenian verbal system

This tables show that the TAM system of Modern Armenian verbs is organized into tenses exhibiting several types of morphological contrast:

- The stem marks aspectual contrast: the imperfective stem (also called present stem) contrasts with the perfective stem (also called aorist stem). One can note that a great variety of moods (subjunctive, declarative, conditional, imperative for regular primary verbs ${ }^{4}$ ) are formed from the present stem whereas only declarative moods are formed on the aorist stem.

4 Imperative singular is formed, depending on the inflectional verb class, from a present stem (regular transitive verbs) or aorist stem (non-primary inchoative, causative verbs or non-regular primary verbs, such as ker 'eat!', actually the bare aorist stem). Imperative formation diverges significantly from EAM to WMA. 
- Inflection marks temporal contrast between past and present, among other features. All tenses except aorist and imperative are organized into present/past pairs (as shown in all cells in the above tables containing double entries), what Plungian (2006) referred to as "temporal mobility". Aorist is the only inflected tense not exhibiting this property.

These types of contrast are well known amongst Indo-European languages, and are exhibited by Old Armenian, but a third type has become an organizing principle in the verbal system at the modern stage:

- Formation, synthetic (stem+inflexion) or analytic (particle ${ }^{5}+$ inflected form, or auxiliary + non-finite form), is associated with modal marking. The presence of a particle marks assertive status (actualisation, in Culiolian terms), while the presence of an auxiliary marks the relation to the situation of utterance. The fact that these strategies can alternate between affirmative and negative forms of the same tense (cf. the present in WMA, table 1) demonstrates that they are two expressions of the same operation.

Thus, we see in Tables 1 and 2 that tenses can be classified by their weight from "lightest" to "heaviest": ${ }^{6}$

\begin{tabular}{|c|c|c|c|l|}
\hline Stem & Inflection & $\begin{array}{c}\text { Tense } \\
\text { correlation }\end{array}$ & $\begin{array}{c}\text { Analytic } \\
\text { form }\end{array}$ & \multicolumn{1}{|c|}{ Concerned tenses (except negation) } \\
\hline$x$ & $x$ & & & singular imperative \\
\hline$x$ & $x$ & $x$ & & aorist \\
\hline$x$ & $x$ & $x$ & $x$ & $\begin{array}{l}\text { subjunctive present/imperfect } \\
\text { present/imperfect; future/future in the past } \\
\text { and conditional; present perfect/ } \\
\text { pluperfect and over-auxiliated forms ; } \\
\text { perfect2/ plusperfect2 (evidentials) ; semi- } \\
\text { grammaticalized periphrastic forms (+all } \\
\text { the negative forms, including prohibitive) }\end{array}$ \\
\hline
\end{tabular}

Table 3: Weight hierarchy of verbal forms in Modern Armenian

The hierarchy shown in Table 3 demonstrates that the aorist is, as expected from the cross-linguistic definition of the category, one of the most minimal morphological forms of the system. Its assertive status, however, seems to be

5 We have chosen to label as "particle" all preverbal markers of tense, whether prefixes or separate words. Concerning $k(\partial)$, it appears to be a word (proclitic) in WMA and a prefix EMA, but even if grammaticalization seems to have been achieved at different periods in each variant, the fact that they are written with or without a typographical gap has no relevance to their nature.

6 There is no systematic correspondance between EMA and WMA tenses, and when a correpondance is shown, marking strategies may not match, but this does not affect the distribution in table 3. 
in stark contrast with neighboring forms in the hierarchy, a paradox also found in other languages (cf., for example, in Hindi, the aorist and the counterfactual as the only synthetic forms of the system). The aorist, as both an assertive and actualized tense (an indicative tense), has the same weight as the subjunctive, which is non-assertive. However, the aorist is differentiated from the subjunctive ${ }^{7}$, as from all inflected tenses, by the fact that it does not exhibit pair opposition of present/past.

As such, we can see from Tables 1, 2 and 3 that the aorist occupies a totally asymmetrical position in the verbal system of Modern Armenian which has already been noted in several studies, the most recent being Plungian (2006) and Giorgi \& Harutyunian (2011). Plungian emphasizes the fact that the aorist exists outside the system of temporal past, while Giorgi \& Harutyunian go so far as to analyze the aorist as a perfective without temporal marking, in order to account for future tense functions of the aorist in Modern Armenian.

It follows from the above that two main questions arise about the status of the aorist in Modern Armenian:

- Given that it lacks a marker of actualization (either auxiliary or particle), is the aorist an indicative tense? ${ }^{8}$

- Given that it does not exhibit a temporal opposition, is it a past tense?

In answering these questions, we are essentially questioning the relationship between aorist and preterit. Armenian grammatical tradition labels this tense anc 'yal kataryal, "perfect past", that is, considers it as a preterit in the sense given above.

Let us return to the analysis of Giorgi \& Harutyunian. The authors (2011: 98), relying on relevant sources on diachrony of Armenian, correctly note the fact that the stem of the Armenian aorist, historically marked by the morpheme -c , has an aspectual meaning, rather than temporal. However, they fail to take into account the flexional morpheme of the aorist, which is undeniably a mark of past tense. Although the aorist does not exhibit pair opposition, it is nonetheless clear that the flexional morpheme of aorist, despite the irregular paradigm, is a past morpheme. It is therefore impossible to deny that the aorist is a form of perfective past. This is obvious for regular verb classes

7 “Tense correlation” parameter doesn't have the same status as other ones, it shows how the subjunctive, being a synthetic tense (with the same quantitative weight), is higher in the inflectional hierarchy than the aorist, as it exhibits tense correlation.

8 Plungian, considering only EMA, connects modality with temporal mobility (in EMA grammar, what we have labelled Future 3 is called conditional, and what we called future 2 is called obligative). Indeed, the fact that present is also an auxiliated form in EMA leads one to conclude that periphrastic model characterizes the indicative tenses, all remaining tenses having a marked modal meaning. 
such as grel 'to write', but it is also the case for classes with type 2 inflection, such as amusnanal 'to marry'

\begin{tabular}{|c|c|c|c|c|c|}
\hline present & imperfe & aorist & present & imperfect & aorist \\
\hline 1sg gre-m & gre-i & grec`-i & amusnana-m & amusnanay-i & amusnac`-a \\
\hline 2sg gre-s & gre-ir & grec`ir & amusnana-s & amusnanay-ir & amusnac`-ar \\
\hline 3sg gre-ø & gre-r & grec -ø & amusnana-ø & amusnana-r & amusnac'-av \\
\hline 1pl gre-nk & gre-ink & grec'-ink & amusnana-nk & amusnanay-ink & amusnac’ank \\
\hline 2pl gre-k & gre-ik` & grec'-ik' & amusnana-k’ & amusnanay-ik’ & amusnac’ak’ \\
\hline 3pl gre-n & gre-in & grec'-in & amusnana-n & amusnanay-in & amusnac`-an \\
\hline
\end{tabular}

Table 4: Aorist and temporal inflection

For the regular verb classes, the -i- vocalism, shared with imperfect, is the mark of the past. The consonantal isomorphism of the 3sg aorist inflection ($\mathrm{ir} /$-ar) shows that type 2 is no different.

Furthermore, we can morphologically characterize the Armenian aorist as:

- Perfective past (past inflection on perfective stem)

- Synthetic in its formation

- Not exhibiting a pair opposition of present/past.

On the semantic level, characterizing the aorist as a past perfect is supported by the great number of occurrences with a preterit meaning, but this does not represent all observed uses in the language (neither in Armenian grammars nor in corpora). It seems then that we have to take into account the remaining formal characteristics in order to better define the nature of the aorist. By suggesting the criteria of temporal mobility, Plungian questions the indicative nature of the aorist, pointing to the importance of the modal parameter.

I agree with Plungian, in that the modal dimension is a key to the analysis of the aorist. But Plungian's analysis is biased by the fact that he considers the indicative tenses to the exclusion of the rest of the verbal system. The conclusions will be different when we observe the aorist as part of a modal continuum without categorizing it a priori as an indicative. Thus, my hypothesis is that mood does not structure the Armenian verbal system in a binary way, but rather in a scalar logic correlated to the hierarchy of morphological weight shown in Table 3. I propose to restate Plungian's query as "being in the neighborhood of the imperative and subjunctive in the weight hierarchy of Armenian tenses, is the aorist an indicative tense?”.

Diachronic development of actualization-marking strategies in Armenian verbal system, which illustrates processes that are cross-linguistically well-

9 Verbs choosen here belong to flectional classes that behave identically in EMA and WMA, but that don't show the same inventory of verbs in the two variants. 
known, ${ }^{10}$ validates this scalar logic, and confirms that the label of "indicative" would do well to be replaced by the more flexible notion of actualization marking. This approach requires a parameter linked to modality: enunciative status, i.e. the assertive type of the utterance in which aorist occurs.

In the linguistic tradition that arises from Benveniste and Culioli, this parameter is integrated to the core of the grammatical analysis, instead of being considered as a specific level of analysis (as, say, pragmatics is). Some basic notions of this theoretical framework are especially helpful here. The first of these is the distinction between récit (narrative register) and discours (discursive register) formulated by Benveniste ${ }^{11}$ as structuring oppositions of enunciative instance and tense, and, as such, being in charge of personal pronouns and past tense use in French. Then, basic notions of Culioli's theory of assertion, describing the situation of enunciation ( $\left.\mathrm{Sit}_{0}\right)$ as the conjunction of an enunciator $S_{0}$ and the moment of the utterance $T_{0}$. We also propose, along with Culioli, to break down the process of assertion of an utterance like "The sun is shining" as follows:(1) I say (2) "The sun is shining" (3) is the case, where (1) represents the enunciative instance, (2) the propositional content and (3) the truth-value granted by the enunciator.

In fact, following Cohen's logic (1985), the diachronic stability of the Armenian aorist, consistently noted by linguists like Markarian (2004:435), is remarkable and seems to reflect specific properties with regard to actualization. One might assume that the aorist has been exempt from the diachronic pressure that affected other assertive tenses, because its assertive value is fundamentally related to narrative register. On the contrary, however, the multilayered actualization observed diachronically in the present tense is the legacy of periphrastic strategies initially serving as optional discourse markers and progressively being grammaticalized. ${ }^{12}$

From this point on, in order to draw a clear picture of the Armenian aorist, connecting its formal and semantic properties, we will examine the uses of

10 D. Cohen (1985) describes the process that, in the diachrony of Semitic languages, leads to the shift of the former present into a subjunctive, by creating a new present form with a more explicit actualization marking. In a similar way, Old Armenian subjunctive, a morphologically heavy form, was replaced by old present forms, while the new periphrastic present was appearing in Modern Armenian.

11 On the distinction between the concept of "histoire", initially proposed by Benveniste, and the one of "récit" used in this paper, see Vogüé (1989).

12 This is what occured in Armenian with particle $k$-/ka, grammaticalized during the Middle Armenian period (this stage of the language is attested only in the Western area, for historical reasons), going back to the defective verb $k a$ 'to be held, to stand', (1) originally used in collocation with stative verbs: $\underline{\mathrm{ka} u}$ mna 'he stands and remains', (2) later with all kinds of verbs, until (3) its grammaticalization, in Middle Armenian, as $k u$, and (4) the generalization of its allomorph $k$-/ka, which has become, in WMA, the mark of present indicative (actualized) by contrast with the present subjonctive. 
the aorist in Modern Armenian, as described in grammars, and as observed in the corpus (cf. footnote 2). We will attempt to refine the characteristics of each category of use and relate them to the specific features of the aorist in the Armenian verbal system. We will first examine meanings observed in the narrative register, which are more homogeneous, and then, the more heterogeneous meanings observed in discourse.

\section{Meanings of aorist in Modern Armenian}

In (Donabedian 1998), I set forth a characterization of the WMA aorist through an enunciative lens, grounded in three distinctive properties of this tense: that it is eventive, compact, and non-anchored to the situation of utterance ( $\mathrm{Sit}_{0}$, characterized by $\mathrm{T}_{0}$, the time of utterance, and $\mathrm{S}_{0}$, the utterer, following Culioli), which fit with the framework used across Culioli-inspired studies of the aorist in diverse languages (Guentcheva 1990, Vassilaki \& Tsamadou 1995, Montaut 2006a, 2006b).

This section aims to show how these three properties manifest across uses of the aorist in Armenian, and why they are more effective to explain the very nature of the aorist than formulations frequently appearing in grammars (be they issued from the Armenian linguistic tradition, ${ }^{13}$ or typologically-inspired, as Dum-Tragut's (2009) grammar).

These three properties allow us to describe the specificity of the aorist, avoiding the numerous counterexamples resulting from some combinatory constraints, often assumed in grammars (semantic property of the event, incompatibilities concerning the verb or the context, etc.), as shown below.

It is probably the fear of counterexamples that causes Maslov (1981: 248) to use only negative formulations to describe the aorist in Bulgarian, for which he has been criticized by Seiler (both cited in Guentcheva, 1990: 94): "The aorist denotes a past action (or an action thought to be past) without considering this action in its own progression and without taking into consideration the relationship to the moment of speech."

The benefit of this formulation is that, although the author may not be relying on an enunciativist framework, he nonetheless places the intention of the

13 From Abeghian in early 20th century through Markarian (2004). 
speaker at the center of description, and avoids stating incompatibilities which may easily be disproven. ${ }^{14}$

By applying the three above parameters to Armenian examples, we will demonstrate that the aorist expresses an enunciative choice made by the speaker, more than it does some constraints defined by the referential background (event type, duration of the event, etc.) or by the co-text (compatibility with certain adverbs, relationship with other events, etc.), which actually can be only tendencies, and not rules.

We aim to draw a distinction between narrative uses (récit), a register characterized by a temporal reference constructed in the past, disjointed from the situation of utterance and from its temporal and enunciative anchorings (repère following Culioli), and discourse uses, where temporal location is calculated in reference to $\mathrm{T}_{0}$.

\subsection{Narrative uses (récit): the "preterit” meaning}

Within the narrative register, the temporal meaning of the aorist is mainly past perfective, according to the Armenian denomination of the tense. In fact, past perfective is the meaning referred as prototypical for the aorist, as it used to be in many Indo-European languages like Modern Greek (Vassilaki \& Tsamadou 1995:46), Bulgarian (Guentcheva 1990), Persian (Lazard 1957: 141, Lessan-Pezechki 2002) or Hindi (Montaut 2006a).

\section{a. No anchoring to the situation of utterance (disjunction from $T_{o}$ )}

This property is intrinsic to the very nature of the narrative register, in which discourse parameters are suspended: the temporal relation of the aorist to the moment of the enunciation can be expressed by adverbials (sometimes, when I was young, last year, ten days ago, yesterday, etc.). Their function is to set a temporal reference for the narration, that can further be disjointed from time of the speech event, allowing the speaker to express fictions or tales, especially in a written form, disconnected from the speech act.

This property is related to one of the formal features of the Armenian aorist: since the present perfect, being an analytic form associating perfective participle and present auxiliary, is actually anchored to the time of the speech event, and hence, regards the relevance of the event for the time of speech (resultative, experiential meaning, etc.), the aorist, as a synthetic form, doesn't express such a relation with the speech time and targets the event by itself, throwing the hearer toward the time of the narration.

14 If there is inaccurracy in this formulation, it is rather in the use of the words "action" and "denotes". 
The feature of temporal disjunction, or autonomy from the speech event, explains why temporal anchoring of the aorist event is overwhelmingly contextually marked, either by an adverbial phrase (1):

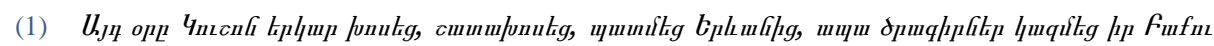

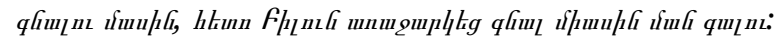

Ayd ôr-a, Kušo-n erkar xos-ec', šataxosec`, patmec ' That day-DEF, Kušo-DEF long talk-AOR3G, rattled.on-AOR3SG, tell-AOR3SG

Erevanic', apa cragir-ner kazm-ec ir Bak'u gnalu Yerevan-ABL then plan-PL formulate-AOR3SG 3SG-GEN Baku go-GEN masin, heto Bilu-n arajarkec ' gnal miasin man.galu about, later Bilu-DEF suggest-AOR3SG go together stroll-GEN

That day, Kusho talked, rattled on, told at length about Yerevan, then he formulated plans for his departure to Baku, then Bilu suggested going for a stroll. (Gurgen Mahari, Trilogy)

or by an imperfect VP laying a temporal framework for the referred event (see (2) and (4) infra):

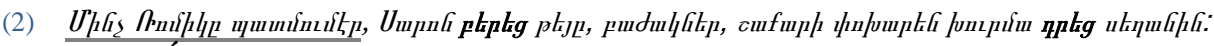
Minč Romik-ə patm-um.êr, Saro-n ber-ec' t’ey-ə, bažak-ner, While Romik-DEF tell-IMPFT3SG Saro-DEF bring-AOR3SG tea-DEF, cup-PL,

šakar-i p`oxaren xurma dr-ec` sełan-in.

sugar-GEN instead date put-AOR3sG table-DAT

While Romik was telling his tale, Sato brought the tea, the cups, and instead of sugar, she placed dates on the table. (Shahen Tatikyan, Destiny)

But a lack of explicit marking of the temporal framework is also possible: the aorist may build a temporal reference by itself, since it functions as a shifting operator from discourse to narrative register within a dialogue:

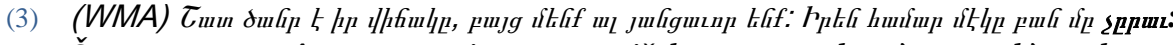
Šat canr $\hat{e}$ ir vičak-a bayc menk al Very heavy be-PST3SG 3SG-GEN condition-DEF but we also hanc`avor enk`. Ir hamar mekə ban ma $\check{\boldsymbol{c}}^{-}$-arav culpable be-PST1PL 3SG-GEN for someone thing INDEF NEG-do-AOR3SG

He is in a hard situation, but we are also culpable. No one did anything for him. (WMA, elicitated example)

This property of disjunction from the time of the speech event $\left(T_{0}\right)$, which is inherent to the narrative register, is a determining factor for the constraints that some linguists ascribe to the aorist's use (i.e. Dum-Tragut 2009: 231) "The aorist is non compatible with adverbs or phrases denoting indefinite

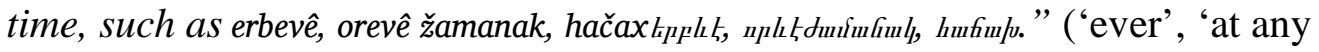
time', 'often'). Nonetheless, an elementary query in the Eastern Armenian National Corpus eanc.net reveals 48 utterances of hačax 'often' + aorist and 50 utterances of erbeve 'whenever' + aorist. So if there is such a constraint, it is a tendency rather than a rule: the disjunction of the aorist event from $\mathrm{T}_{0}$ implies that the event's temporal reference is autonomous, not calculated by 
reference to $T_{0}$, whether contextually specified or not (see example 3 where the aorist constructs its own temporal reference). We will comment some examples where the aorist co-occurs with hačax and erbeve in b. and c. below.

\section{b. A compact and globalized event}

This second property, also exhibited by Vassilaki \& Tsamadou (1995: 46) as characteristic of the aorist in Modern Greek $^{15}$, is likely what encourages grammarians to present the aorist as a non-durative tense, figurated as a point on the temporal axis, since imperfect is figurated as an interval. With nontelic events (due to the lexical semantics of the verb or to its contextual processing), the imperfect sets up a temporal framework (an interval between an initial boundary and a final boundary) since the aorist is a point with no identifiable bounds, as it aims to refer to the event globally:

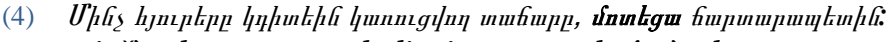

Minč hyur-er-a k-dit-ein kaŕuc`vot tačar-ə

While guest-PL-DEF k-look-IMPFT3PL under.construction temple-DEF,

motec'a čartarapet-i-n

approach-AOR1sG architect-DAT-DEF

While the guests were observing the temple under construction, I approached the architect. (E. Karakhanian, My Memories of A. Khachaturyan)

Markarian (2004: 434), referring to Abeghyan (1965), claims that the aorist refers to an event without duration; while Giorgi \& Harutyunian (2011: 101) mention a punctuality constraint. It is clear that the stake is not the real durativity of the event, since aorist is compatible with stative or durative verbs, as in (7) as well as with iteration: the incompatibility with the adverb hačax 'often' claimed by Dum-Tragut is, in fact, a tendency due to the compact feature of the aorist, and not an incompatibility between aorist and temporal indetermination. That explains why these supposed constraints are not absolute, as examples (5), (6) show:

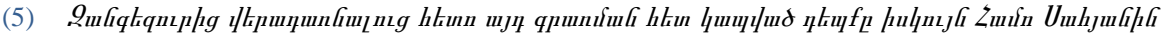

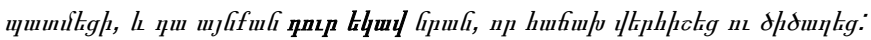

Zangezur-ic veradarnaluc heto ayd grarm-an het kapvac

Zangezur-ABL return-ABL later dem inscription-GEN with related

depk`a iskuyn Hamo Sahyan- DAT patm-ec $\boldsymbol{i}$, ev da

event-DEF actually Hamo Sahyan- in recount-AOR1SG and that

aynk`an tur.ekav nran, or hačax verhiš-ec $u$ cicat-ec

so.much please-AOR3SG 3SG.DAT that often recall-AOR3SG and laugh-AOR3SG

Having returned from Zangezur, I actually recounted to Hamo Sahyan the event related to the inscription, and he liked it so much, that he often recalled it and laughed. (V. Davtyan, In the Beginning was the Word)

15 "Regarding aspect, one can represent the meaning of the aorist stem as a compact interval, impossible to divide. Thus, it has to be conceived as a whole, and the associated event is to be understood as an entire whole, not allowing one to discern a beginning, a middle or an end to it." 


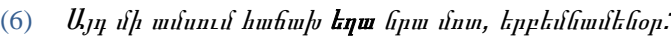

Ayd mi ams-um hacax eła nra mot, erbemn amen ôr. Dem one month-LOC often be.AOR1SG 3SG.GEN close sometimes every day

During that month, I was often close to him, sometimes even daily.

(R. Zaryan, Memoirs I)

The event may be taken as compact, even if the VP refers to an iterative or durative event. Such an assumption requires considering verbal tenses as operators setting an utterance's meaning, rather than markers encoding a referential situation or context. That's what happens in example (6), where the aorist re-categorizes a stative verb as a dynamic event.

\section{c. A dynamic event}

The 'compact' feature is narrowly linked to that of 'dynamic event' (in contrast to stative or resultative events), especially in the narrative register. In example 7, durative events referred by verbs kangnel 'to stay' and nayel 'to look' are caught as compact events and are inserted into the narrative chain:

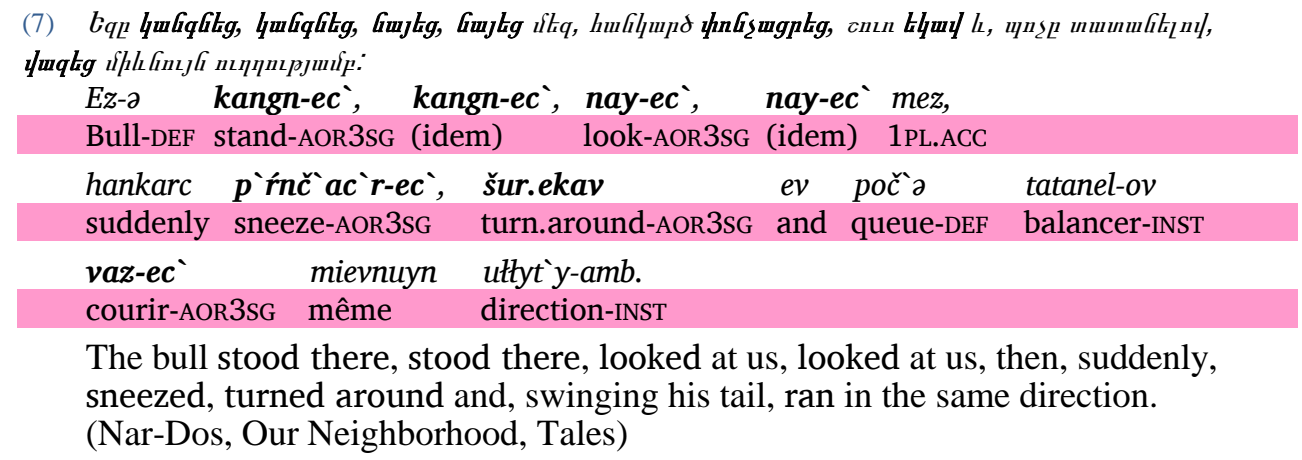

The durative semantics of stative verbs kangnel 'to stop, to stay', or nayel 'to look', reinforced by the reduplication, create an effect of expectation that may be considered as a negative event (a stop, interrupting the movement); here the stative verb is salient regarding to what was expected (the bull was supposed to continue on his way), and hence bear some eventive value.

Guentcheva (1990: 84) considers the occurance of an event (l'occurrence d'événement) as the core feature of the aorist in Bulgarian (le trait le plus fondamental de l'aoriste bulgare). Actually, this meaning is related to the preterit meaning mentioned supra for most of concerned indo-european languages. Markarian (2004: 436) characterizes the Armenian aorist as the tense that grants narration's progression. According to Dum-Tragut (2009: 231), it is used as the main form of narration, especially in a succession of several actions/situations and only if the narrator is a witness of the action.

Compact event is prototypically related to "achievements" (dynamic and telic verbs or events, according to Vendler), what implies that multiple events have 
to be chronologically sequenced. That is, prototypically, the aorist is the tense of the chronologic succession of events. $C f$. (1), and:

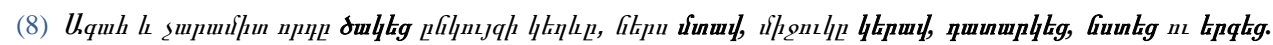
Agah ev čaramit ord-ə cak-ec ənkuyz-i ketev-ə, ners mt-av, Greedy and evil worm-DEF pierce-AOR3SG nut-GEN shell inside enter-AOR3SG mijuk-a ker-av, datark-ec', nst-ec ' u erg-ec`. flesh-DEF eat-AOR3SG to.empty-AOR3SG sit.down-AOR3SG and sing-AOR3SG The greedy and evil worm pierced the shell of the nut, crept inside, ate its flesh, emptied it, sat down and began to sing. ${ }^{16}$ (A. Khnkoyan, Poems and Fables)

According to Montaut (2006b: 188), the Hindi aorist "représente la simple succession de procès révolus sans jugement de la part de l'énonciateur et comme autovalidés", as opposed to the perfect tense, "construisant par intervalle ouvert l'espace de validation du procès, apparaît comme un bilan”, which applies perfectly to Armenian. ${ }^{17}$

The feature compact + eventive explains why sequences of aorist events frequently denote a chronological succession, this later being, however, not strictly the core meaning of the aorist, and, thus, not significant to be a constraint for the use of this tense. Actually, corpora show many utterances of aorist without absolute chronological succession between events, due to the lexical class of the verb (in (7), the first two stative verbs are in fact concomitants), or to a notional succession between events, rather than a chronological one:

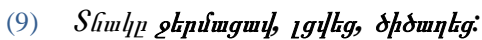
$\begin{array}{llll}\text { Tnak-a } & \text { jermac }-a v, & \boldsymbol{l} \boldsymbol{c}^{`} \boldsymbol{v}-\boldsymbol{e c} \boldsymbol{c}^{\prime}, & \text { cicat-ec }\end{array}$

The house warmed up, filled, smiled.

(M. Sahakyan, It was Spring and it had Snowed)

In example (9), the metaphoric use of the verbs can explain why the chronology is not relevant, but one can also mention sequences of ontologically-related verbs having a cumulative effect that does not affect their eventive meaning, sometimes for emphatic purposes, when verbs are all destined to characterize a single attitude:

16 In Armenian 'sang', but the narrative structure implies a narrative succession of dynamic processes that confer an ingressive value to the aorist.

17 As shown in this example from Barchian (2002: 304). An Armenian professor recounts his arrival in Paris, where no one was waiting for him. There, at night, we partied $\underline{\underline{(\mathrm{PFT})}}$ all night, a

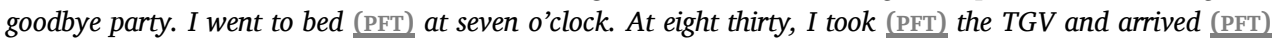
at one in the afternoon at the Gare de Lyon. (Not seeing anyone). I got worried (AOR) and said to myself (AOR), 'he is probably on his way, maybe he will come. The set of perfects has the effect of creating a cumulative result, to highlight the state of exhaustion the speaker was in. The aorist comes in once he is not far from the result, but still in action. 


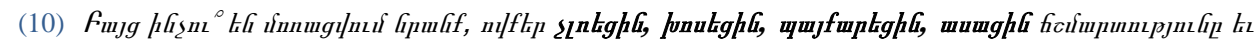

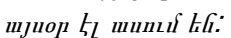

Bayc` inč $u$ en morac` $v$-um nrank`ov-k`er $\check{c}$-lŕec`in,

But why AUX.3PL forget.PASSIF-PST those who-PL NEG-be.silent-AOR3PL

xosec`in, payk`arec`in, asac`'in čšmartut'yun-ə ev

speak-AOR3PL fight-AOR3PL say-AOR3PL truth-DEF and

aysôr êl asum en.

today also say-PST AUX.3PL

But why do we forget those who were not silent, who spoke up, who fought back, who told the truth and tell it still today? (Azg Daily, 2008.04.05)

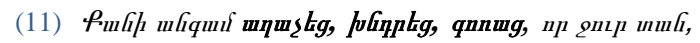

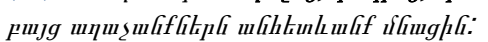

$K$ Kani angam ałač'-ec ${ }^{`}$ xndr-ec goŕ-ac' or jur

How.many time beg-AOR3SG pray-AOR3SG cry-AOR3SG that water

tan bayc` ałač ank`-ner-n anhetevank mnac`in

give.3PL but plea-PL-DEF without.result remain-AOR3PL

Time and again he begged and prayed, screamed for someone to give him water, but his pleas remained unanswered. (Ch. Tatikyan, His Way)

Several verbs tend to co-occur frequently, and behave as quasi-collocations; for example eat, drink, be merry:

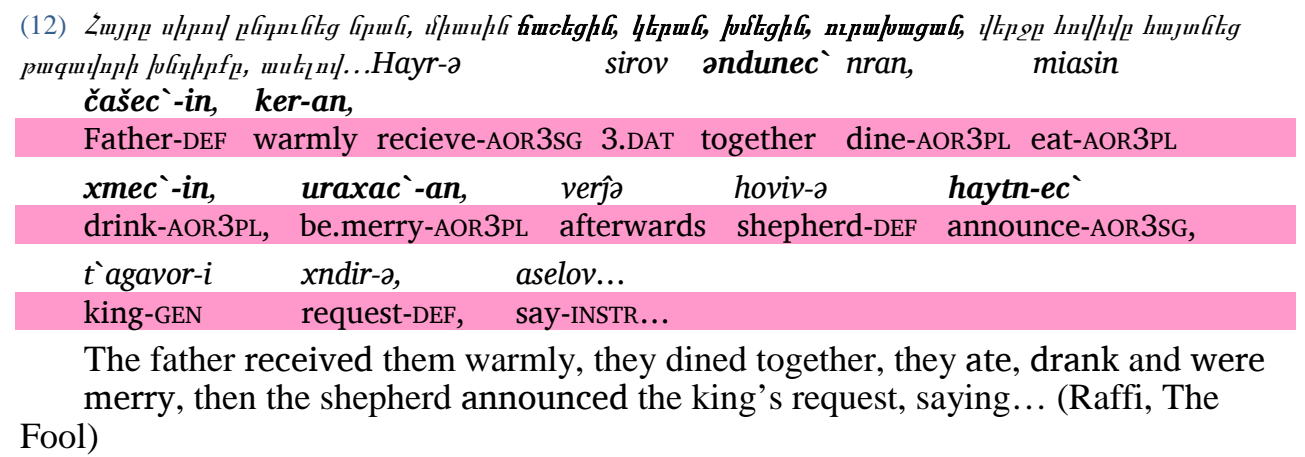

As we see, chronological sequencing of aorist events is the rule for discrete achievement-like events that grant the narrative's progression, but it is not a defining feature of the aorist, since the aorist also allows sequences of nondelimited events, including durative event, which do not move the narrative along as in a sequence, but rather constitute a complex event. Example (12) shows that both types of sequences can co-occur: events (the father received them warmly, they ate, drank, and were merry together, the shepherd announced the king's request) are chronologically arranged, since drank, were merry together, that follow they ate, are breaking down the complex event ate (iterally: dined), in order to emphasize the narration.

Sequences of aorists may reveal other kinds of relationships between constituent events, some of them being explicit (cf. henc' 'as soon as' in (13)) or contextually recoverable ( $c f$. the causal relationship in (14)). 


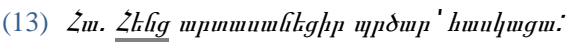

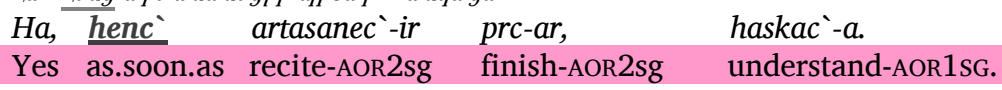

Yes. As soon as you finished reciting it, I understood [that it wasn't your poem]. (Aravot Daily, 18.11.2006)

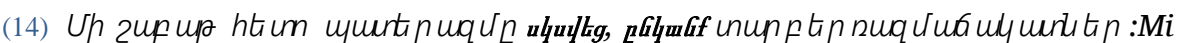
šabat heto paterazm-ə sksv-ec ', onk-ank tarber razmačakat-ner. One week later war-DEF start-AOR3SG fall-AOR1PL different front-PL

One week later, the war started, and we found ourselves on different fronts. (Arshak, the Rooster).

The common feature of all these kinds of relationships between aorist events is that, having no anchoring to the situation of utterance, they have to build their anchoring contextually. Thus, in a sequence of aorists, events anchor to each other in a way that depends on their lexical semantic properties and/or on the context, the prototypical chronologic sequence 'veni, vidi, vici' being just one of the ways of anchoring aorist events among themselves.

The eventive feature of the aorist explains also why the incompatibility of the aorist with erbevê 'ever', mentioned by Dum-Tragut (2009), is not an absolute constraint. In a declarative sentence, the aorist with erbevê, which implies a negative verb, aims to assert that the referred event never occurred during the concerned timeslot. Verbs may be achievements (non-durative):

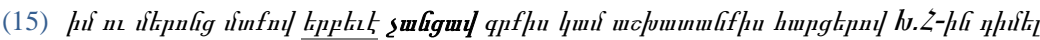
Im $u$ meronc mtk'ov erbevê čanc'-av grk'i-s 1SG.GEN and our.POSS1PL mind-inst never NEG-cross-AOR3SG book-GEN-POSs1 or ašxatank'-is harc'-er-ov X. H.-in dimel work-GEN-POSS1 issue-PL-INST X. H.-DAT seek.out.

It never crossed my mind or our minds to seek out Khachik Hratchian with regard to my book or my work. (Aravot Daily, 29.10.2005)

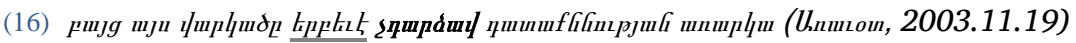

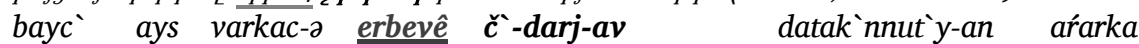
But this theory never NEG-become-AOR3SG examination-GEN object But this theory never became the object of (critical) examination. (Aravot Daily, 19.11.2003)

but even with durative verbs, the aorist may occur by re-categorizing the verb as a compact event. Example (17) can be translated with a phasal verb (give into despair) that reflects the compacity of the aorist event:

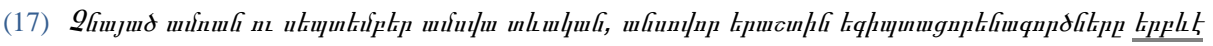
¿hnumuhunulkgha: čnayac amŕ-an u september ams-va tevakan, ansovor erašt-in Despite summer-gen and September month-gen continuous unusual dryness-DET egiptac 'orenagorc-ner-ə erbevê $\check{c}^{\prime}$-husahatvec'-in corn.grower-PL-DEF never NEG-despair-AOR3SG

Despite the unusual, continued drought of the summer and September, the corn growers never despaired. (Zangezur, 07.10.1986) 


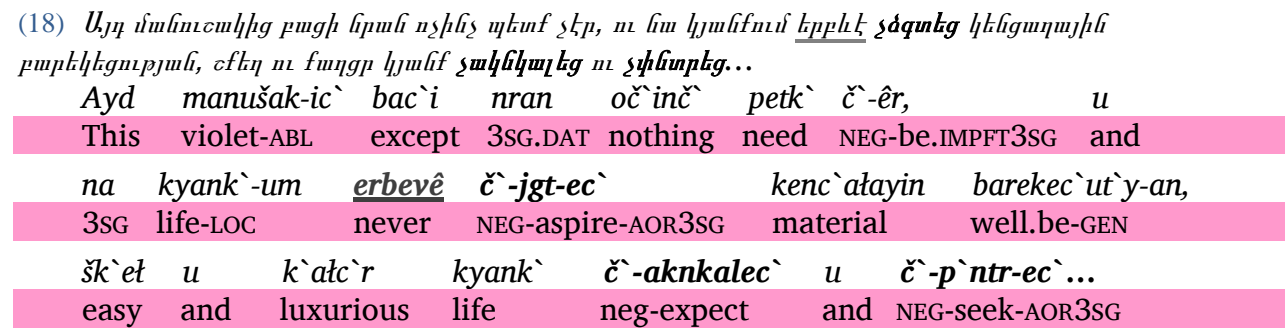

Apart from this violet, she did not need anything, and never in her life was she tempted by material well-being, nor had she hoped for or sought a luxurious and easy life... (Vahagn Davtyan, In the Beginning was the Word).

Thus, when erbeve sights a long timeslot, as in example (18) throughout her life, whatever the semantics of the verb, the aorist builds the process as an event. In (17) and (18), the eventive feature can be glossed 'this thing did not happen'. What is asserted (negated) is the happening of a state of affairs as an event.

As has been shown, the eventive feature of the aorist, closely related to compacity and to non-anchoring to the situation of utterance, takes various semantic forms, beyond the alleged constraints of grammars, that are to be considered as one of the displays of these features.

\section{d. Modal meaning}

Grammars often mention another modal feature of the aorist. According to Guentcheva (1990:107), the aorist refers to an event that can be taken for granted, that makes no doubt, and this is what distinguishes the aorist from the mediative/evidential tense (1990:94). Dum-Tragut (2009:231) assumes that the aorist occurs "only if the narrator is the witness of the action".

As a matter of fact, this meaning is not relevant to the narrative register in Armenian, where certainty and witnessing are not marked features of the aorist, as demonstrated in numerous counterexamples as (20), and (29-36). Most of the time this feature is mentioned by grammarians as a distinctive feature of the aorist by contrast with tenses marking doubt, non-certainty or non-witnessing (evidentials, or even pluperfect), but in fact only discourse register is concerned by this contrast, since in the narrative register aorist seems to be unmarked in this regard.

\subsection{The aorist in a discourse situation:}

The situation of discourse may allow narrative-like uses of aorist, as in this example which exhibits a register-switching inside the sentence (marked //): 


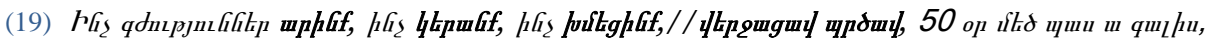
Inč gžutyun-ner ar-ink, inč ker-ank', inč xmec'-ink

What folly-PL do-AOR1PL what eat-AOR1PL what drink-AOR1PL verjac $-a v$ prc-av, 50 ôr mec pas a galis end-AOR3SG finish-AOR3SG 50 day big Lent aux.3sG come.PST

What follies we committed, what we ate, drank // That's over, now 50 days of Lent are coming. (P. Proshyan, A Matter of Bread)

The first sequence of events ('we have eaten/drunk') is narrative, since 'it's over' switches into discourse register, characterized by its temporal anchoring in the situation of utterance and the subjective involvement of the speaker.

In (19), the switch from one register to another is quite obvious from the context, but in a discourse situation it is not always easy to settle on precise parameters when the speaker switches to narrative register. For example, verjapes hasa 'finally I arrived' is purely discursive, but taksiov eka 'I came by taxi' may be discursive or narrative, depending on the context (on the one hand, as a reaction to an argument or a presupposition of the interlocutor, supposing that the speaker could not come, on the other hand, in a context like 'you know, today I came by taxi because last time the bus was terribly slow').

We will not give here a detailed study of parameters that distinguish between these two uses of the aorist, due to space constraints. Rather, the aim of this section is to analyze the uses of the aorist that imply an anchoring to the situation of utterance. We will see a) that the feature related to the anchoring to the situation of utterance reveals some modal, apparently different and centrifugal meanings, but all related to this core property, that they are revealed through various semantic values, and b) that they have also some aspectual effects. This will allow us to examine c) sentences where the aorist exhibits the "future" meaning, to show that this meaning is consistent with the remaining discourse meanings of the aorist, rather than being a "paradoxical" meaning.

\section{a. Anchoring to the situation of utterance and the modal meanings specific to the discourse register}

A discourse situation implies the existence of points of reference, the main ones being the moment of speech and the speaker, tagged respectively $\mathrm{T}_{0}$ and $\mathrm{S}_{0}$, according to Culioli's Theory of enunciation. We have stated that the aorist's core value is the lack of anchoring to the situation of utterance. Nevertheless, the aorist can occur in discourse situations. The combination of these two apparently incompatible features leads to some modal meanings:

- according to Benveniste, in the discourse register -unlike in the narrative register- the validity of a statement relies on the speaker, which allows a shift to modal meanings such as comment, personal judgement, or emphasis on assertion, as in examples (19) and (20). 
- the eventive feature of the aorist allows a specific type of assertion wherein the event is referred to as happening out of the speaker's consciousness, but recorded by the speaker. That creates the possibility of modal effects related to awareness, possibly to sudden awareness, as in example (21).

Some contexts and semantic types of verbs facilitate the saliency of one or the other of these meanings. Moreover, the features often attributed to the aorist in grammars, such as "event observable at the moment of the speech", "witnessing", "certainty", follow from such contexts or semantic types and are just one of their possible manifestations.

The first of them is illustrated in the following example:

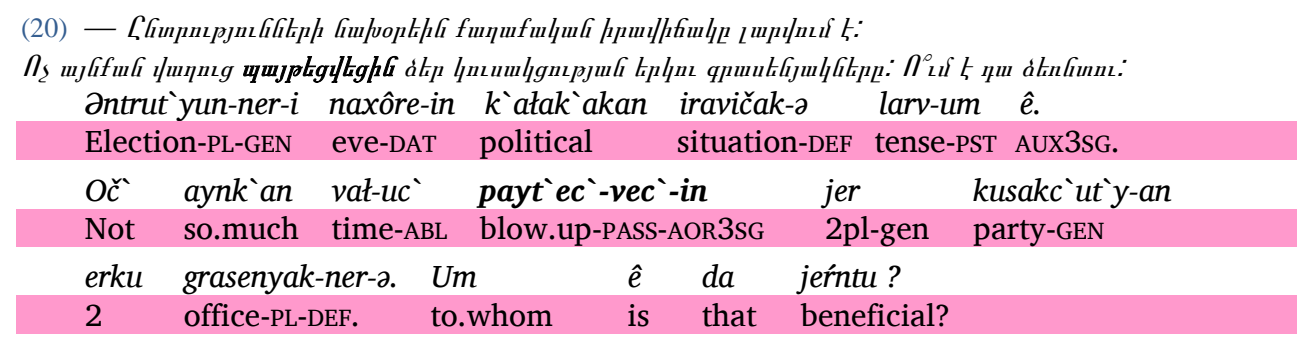
On the eve of the elections, the situation is tense. Not long ago, the two offices of your party were blown up. To the benefit of whom? (Aravot Daily, 2007.05.10)

Here neither the event nor its results are "visible", but the event is referred to as relevant for the argumentation, opening the way for a comment or an interpretation. These attributes are associated with a strong assertion. A meaning interpreted by grammarians as "witnessing” or "certainty" can appear in this case:

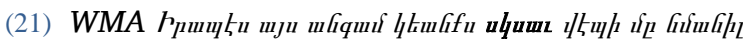

Irapês ays angam kyank'-s sks-aw vêp-i mə nmanil.

Truly this time life-POSs1 begin-AOR3sG novel-DAT INDEF resemble.

This time, truly, my life has begun to resemble a novel. (WMA)

In example (21), the event is made discrete by the use of ays angam 'this time'. The subject becomes aware of the event and he expresses it immediately. In this use, the aorist shares some properties of the evidential/admirative ${ }^{18}$ tense: $^{2}$ the awareness of the event simultaneous to its enunciation is also one of the modal features that characterize the Western Armenian evidential past in the discourse register (mirative meaning), as shown by the temporal translation of example (21) into pluperfect:

(21)a.Irapês ays angam kyank'-s skser.êr vêpi mə nmanil.

Truly this time life-POss1 begin-EVID3sG novel-DAT INDEF resemble.

This time, truly, my life has begun (EVID) to resemble a novel.

18 This can explain, why in Hindi the aorist and not the perfect expresses the admirative. 
In a discourse situation, with a reference time $\mathrm{T}_{0}$ like in example (21), the system allows for the contrast of the aorist and the evidential, the latter carrying a stronger sense of a surprising, unexpected, amazing event. But when translating the statement into $T_{-1}$ as in example (21a), which is out of the situation of discourse, this contrast is no longer possible, which shows that the meanings described in this section are in fact specific to the discourse register. ${ }^{19}$

The two features described above lead to several modal meanings, depending on the verb's semantics, on context, and sometimes on collocations. Some of these meanings have been mentioned for other languages as well:

\section{Internal states (WMA)}

(22) UikophyuJ

Anôt'ec'a

be.hungry-AOR3SG

I'm hungry
(23) 2ufiánuguj

Janjrac'ay,

feed.up-AOR1SG

I'm fed up! ${ }^{20}$

This meaning is similar to the inchoative use of verbs referring to subjective

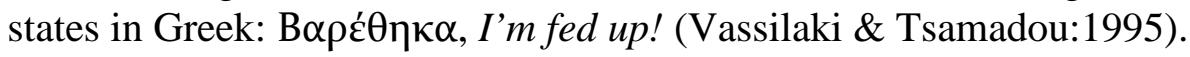

Change of state (WMA and EMA)

(24) $U_{p}$ litig

Mt'nec'

darken-AOR3sG

It's dark out

Prospective meaning

This meaning is mentioned by Dum Tragut (2009: 232) as ingressive meaning with motion verbs (gnac'i), and corresponds to the label aoriste d'anticipation used by Lessan-Pezechki (1998) for Persian.

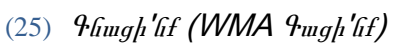

Gnac'ink' (WMA gac'ink')

leave-AOR1PL

Let's go!

This last meaning reflects the same property Vassilaki \& Tsamadou mention with regard to the inchoative meaning of the aorist with verbs of state or of change of state, verbs referring to the outcome of a physical process

19 On the aorist / evidential pluperfect complementarity in WMA, see Donabedian (1996).

20 Additionally, even if these utterances show affinities with the evidential, we can establish minimal pairs, anôt 'ec 'ay (aorist) not being interchangeable with anôt ec 'er em (mediative or evidential). The latter opens upon an analysis of causes, while the aorist expresses a simple constatation and is not oriented toward and action in consequence. 


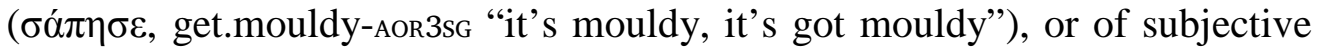
states, as in examples (22) and (23).

Only such utterances, which are specific to the discourse register (awareness, prospective meaning), can match the 'concomitant with the moment of the speech' feature, mentioned in grammars as characterizing the aorist. Unfortunately, no grammar mentions this constraint. As we have seen, the modal specificity of this use is also connected to an aspectual one: change is a major component for all these meanings.

\section{b. Compact event and aspectual consequences}

Dum Tragut (2009: 231), who does not make use of the notion of discourse register, mentions that "In direct speech [the aorist] refers to the action that had occurred immediately before the moment of speech. The result of this action must be observable at the moment of the speech." The feature immediately before, which leads to numerous counter-examples in its literal interpretation, is actually, through the proximity with the moment of the speech, aiming for the eventive meaning of the aorist, which allows the speaker to capture the event itself, since the perfect captures in $\mathrm{T}_{0}$ the result of the event, ${ }^{21}$ as shown by glosses in brackets after the translation:

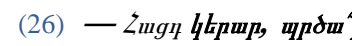

Hac'-d ker-ar prc-ar?

Bread-POSS2SG eat-AOR2SG finish-AOR2SG?

That's it, you ate your meal? [It's done?]

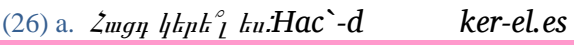
Bread-POSS2SG eat-PFT/EVID.2SG ?

You have eaten your meal? [You're not hungry? I can clear the table?]

This contrast functions with various semantic types of verbs (in (26), an activity verb), beyond the well-known case of achievement verbs like 'to arrive' where the aorist, in (27), marks teleology (it's done, I finished, I did it), when perfect in (27a) marks the result (see the translation 'he is here'):

(27) WMA Y.

Verjapes has-a.

Finally arrive-AOR1SG

Finally I arrived. (WMA)

This example may have two eventive interpretations: 'it's done, I did it' (emphasizing the accomplishment, which we can label as QNT, following Culioli) or 'such a thing happened' (qualitative saliency, emphasizing the

21 The observable result at the moment of the speech feature undoubtedly corresponds to the same intuition, but this formulation is clumsy and difficult to interpret because this feature is generally used to describe the resultative meaning of the perfect. 
very nature of the event, which we can label as QLT). By contrast, in example (27a), the perfect allows only a resultative interpretation:

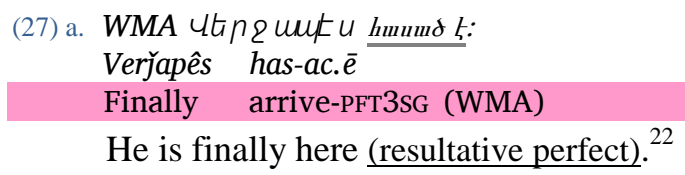

The eventive meaning can apply as well to stative verbs, as seen in example (28), with a strong value of intentionality, of act, which affect the semantics of the verb, reinterpreting it as an eventive verb:

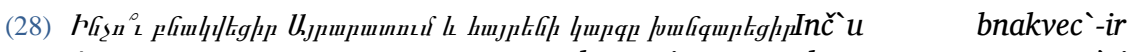
Ayrarat-um ev hayreni karg-a xangarec'-ir? Why reside-AOR3SG Ayrarat-LOC and ancestral order-DEF disturb-AOR2SG.

Why did you live in Ayrarat and defy the order of our ancesters? [dared to live, decided to live], (S. Harutyunyan, The Armenian Romantic World)

The meaning of compact event surfaces in these examples through dynamic and telic features, but also with an emphasis on one of the boundaries of the process, either its beginning (cf. inchoative meaning in (21-24)), or its end (26-27). As we can see, whatever the event class of the verb lexicality inaccording to Vendler's typology (state, activity, accomplishment, achievement) the use of the aorist leads to the recategorisation of the event into an achievement. The same phenomenon can be assumed to explain what is called in Modern Greek inchoative meaning or resultative state of telic verbs by Vassilaki \& Tsamadou, no matter what the lexical semantics of the verb, the use of the aorist recategorizes it in order to allow an emphasis on the boundaries.

In other cases, as in (28), when the target is "the event by itself", "its very nature", "the fact that such an event happened" (i.e., according to Culioli, when QLT, meaning the notion, is emphasized, rather than QLT, meaning the utterance with its boundaries), the event is given as compact, that is, as a globalized event, taken as a whole, and the meanings of the aorist merge with those of the narrative register.

These two manifestations of the meaning of compact event (arising of an event, with emphasis either on one of its boundaries (QNT), or on the notion expressed by the verb (QLT)) also appear in the meaning 'if ever...' associated with the future values of the aorist.

\section{c. Non-actualized aorist and the supposed future meaning}

22 In isolated sentences, the third person as in $(27 \mathrm{a})$ is coherent with the perfect, $\left(\mathrm{S}_{0}\right.$ notices something in the situation about a third party), since the first person converges with the aorist $\left(\mathrm{S}_{0}\right.$ states an event at the moment it occurs). In longer contexts, one could certainly combine the first person and the perfect, or the third person and the aorist. 
The possibility for the aorist to refer to a future event is sometimes presented as an exotic feature of Armenian. We will show in this section that, not only does this meaning exist in other languages as well, ${ }^{23}$ but, moreover, that it is predictable from the invariant features of the aorist defined and illustrated above. Finally, we will show that "future" is not the most appropriate label for this meaning.

\section{- Overview and state of the art}

Examples presented in this section are drawn from Dum-Tragut (2009: 231), who introduces them as follows: "In subordinate conditional clauses the aorist is often used to denote a single, unexpected action in the future or an iterative unexpected action." 24

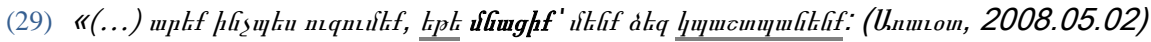

arek' inčpes uzum.ek', et`e mnac'-ik', menk’ jez kpaštpanenk' Do as want-PST2PL if stay-AOR2PL, 1PL 2pl.ACC defend.FUT/COND.1PL

Do as you like, if you stay, we will defend you. (Aravot 2008.05.02)

Giorgi \& Harutyunian (2011) combine under the same label (aorist with future meaning) examples like (25), with prospective meaning or intentionality meaning, ${ }^{25}$ and examples like (29), where the event expressed with the aorist creates a hypothetical framework being the validity condition for the event expressed in the apodosis.

Actually, what differentiates these types is the modal and assertive dimension, which is central for the examples analyzed in this section. In example (25), the event is fully asserted, and even if the temporal value does not match the referential situation, it is assumed by the speaker (as an “anticipation”). By contrast, in examples like (29), the aorist does not have an assertive meaning, the truth-value of the propositional content is not asserted by the speaker as valid for the situation of discourse (that is, the event is not actualized), it is considered an hypothesis that, in examples with future meaning, creates a framework for another assertion, and in examples with gnomic meaning, refers to a general knowledge not linked to the situation of discourse.

23 Cf. Lessan-Pezechky (2002) for Persian, and Vassilaki \& Tsamadou (1995): $\pi \varepsilon i ́ p \alpha \xi \varepsilon \varsigma \tau о$

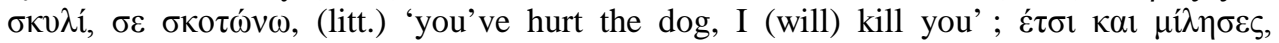
$\chi \alpha ́ \theta \eta \kappa \varepsilon \varsigma$ (litt.) 'you talked like that, you're screwed', where the protasis is the aorist, but the apodosis may be in the present or in the aorist, as in Armenian. In Russian, it is the present perfective that plays this role, which may have influenced Giorgi \& Harutyunian (2011) in their interpretation of this form.

24 These utterances, said to be of future meaning, appear only in Eastern Armenian.

25 What Lessan-Pezechki 1998 calls "the aorist of anticipation”, also attested in Modern Greek with ท́ $\rho \alpha \alpha$ 'arrive-AOR3sG', litt. 'I arrived!' from a waiter who has not even begun to move toward you. 
By contrast, in some other meanings of the aorist, the unsettling of temporal reference does not involve a prospective meaning. That is the case of the gnomic aorist: ${ }^{26}$

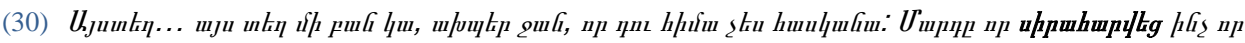

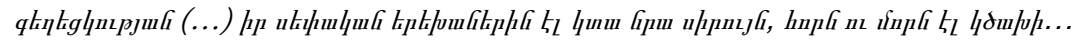

Aystet.. aystet, mi ban $k a, \quad$ axper jan, or $d u$ hima

There, there a thing there.is, brother dear, that you now

\begin{tabular}{|c|c|c|c|c|c|c|}
\hline čes hask & ana. & & Mard-ə & sir & aharv- & inč.or \\
\hline NEG-unde & rstand-FUT, & /COND.2SG & man-DEF & wh & $0 /$ if & fall.in.love- \\
\hline AOR3SG & INDEF & & & & & \\
\hline getec `kut & $y$-an (...) & ir & sep`akan & erexa-ner-n & el & $k t a$ \\
\hline beauty-D & & 3SG.GEN & own & child-PL-DEF & even & give-FUT./COND3SG \\
\hline nra & sir-uyn, & horn & $u$ & morn & el & kcaxi... \\
\hline 3sG-gen & love -DAT & father.DA & AT and & mother.DAT & even & sell.FUT/COND3SG \\
\hline
\end{tabular}

[Here, there is something, my brother, you can not understand now].

The man who falls in love [i.-e. if a man falls in love, once a man falls in love] with something beautiful (...) would give up his own children, would sell his own mother and father... (Dostoevsky)

Or of what Lessan-Pezechki (1998) calls “aoriste modal potentiel”.27

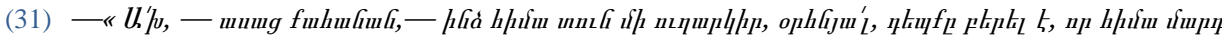

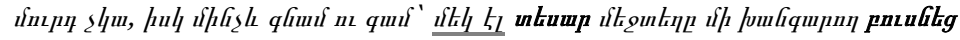

Ax, asac k`ahana-n, inj hima tun mi.ułarkir,

Ah, say-AOR3SG priest-DEF 1SG.DAT now house prohib.send2sG,

ôrhnyal, depk'-a berel.e, or hima mard murd blessed, chance-DEF bring-PFT3SG that now man REDUP

$\breve{c}-k a, \quad$ isk minčev gnam $u$ gam, neg-there.is but until go-1sGSuBJ and come-1sGSUBJ,

mek.êl tesar mejtełə mi xangaroł busn-ec ‘...

suddenly see-AOR2SG in.the.middle INDEF nuisance sprout-AOR3SG...

- Ah, said the priest, do not send me home now, now fortunately there is not a soul here, but by my return, you have seen that a nuisance will have appeared... (Boccaccio).

Incidentally, Vassilaki \& Tsamadou (1995) mention that the gnomic aorist and the 'future' aorist share a common feature: the disjunction from $T_{0}$. We prefer to emphasize the assertive feature, considering that it conditions the

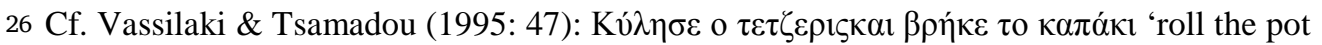
and find the cover'.

27 Appearing after adverbs with a meaning of 'perhaps' (balke, šaajjad), in these utterances it means 'maybe he will come'. Cf. (30): in Armenian, this value appears more so after adverbs or adverbial phrases indicating suddenness, or even a serial construction with the verb 'to see', which expresses also something inadvertent. 
disjunction from $T_{0}$, since the non-validation of the propositional content's truth suspends the temporal value of the aorist. ${ }^{28}$

In order to relativize once more the paradox associated with this "future" meaning of the aorist, it is worth mentioning that example (30) allows more than one interpretation: 'If someone falls in love..., he will sell his father and mother'; 'if someone falls in love...he may sell his father and mother...'; 'once someone has fallen in love, he can sell his father and mother... ${ }^{29}$ In other words, we propose that the specificity of these uses is not the temporal meaning, but rather the modal and assertive property that is able to suspend the temporal value of the aorist in order to emphasize the arising of the event, the change, that is, in the aspectual meaning of the aorist, which is eventive and compact.

In complex sentences containing protasis and apodosis (the most widespread case), the syntactic pattern is not rigid: variation can concern the conjunction (et 'e, 'if', or 'that', henc' 'as soon as', not all of which are illustrated here), or even the lack of conjunction in paratactic sentences, as in example (37). ${ }^{30}$ The aorist is mandatory in the protasis, but there is no constraint on the tense of the apodosis: prospective tenses as future/conditional ${ }^{31}$ in example (29) and (37), future in example (32), optative in example (33), imperative in example (34).

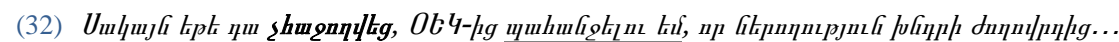
Sakayn yet'e da “̌-hajotv-ec`, OEK-ic` pahanjelu.em, But if that NEG-succeed-AOR3SG OEK-ABL require.FUT1SG or nerotutyun xndri žołovrd-ic' that forgiveness ask.SUBJ3sG people-ABL

But if it does not succeed, I will require that OEK apologize to the people. (Aravot Daily, 05.10.2004)

28 In which Giorgi \& Harutyunian are correct, even if we don’t follow them when they apply this to the aorist more generally.

29 See also in this regard example (35), since example (31), as shown by Lessan-Pezechki for Persian, matches utterances where French uses the past in the future (futur antérieur), which demonstrates that in this context there is a continuum rather than a paradox between past and future meanings of this tense.

30 In Persian, Lessan-Pezechki 1998 gives to these uses, not the label "future", but that of "hypothetical modal aorist", in a subordinate clause with agar 'if'.

31 This tense, designated as "conditional” in Eastern Armenian grammar, has several uses that one could consider to be future. For this reason, we have glossed it under a double label. It appears in the apodosis of conditionals, but also in prospective affirmations (of the type, 'don't worry, I'll come'). 


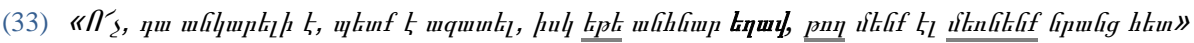
Oč̀, da ankareli $\hat{e}, \quad$ petk'. $\hat{e}$ azatel, $\overline{\text { isk }}$ et e No, that impossible be-3sG, necessary.be-3sG liberate, and if anhnar et-av, tot menk $\hat{\text { el }}$ meŕnenk nranc' het impossible be-AOR3SG, let 1PL ourselves die.SUBJ1SG 3PL.GEN with

No, this is impossible, he must be liberated, and if we do not manage that, may we ourselves perish (optative). (A. Hovsepian, Heart)

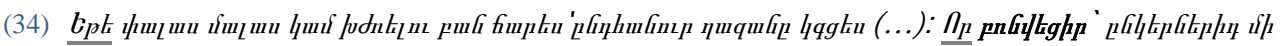

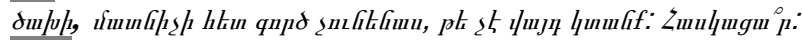

Et’e p’alas.malas kam xžrelu ban čar-es, ondhanur łazanə If rags.etc. or snatch-GEN thing find-SUBJ2sG, communal pot

kgc`es. Or bŕnvec -ir, anker-ner-d mi.caxi, matnič-i put-SUBJ2sG. If be.catch-AOR2SG friend-PL-POSS2 prohib.sell2sG snitch-GEN

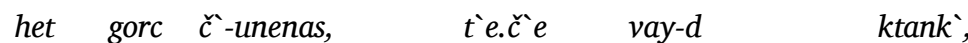
with deal NEG-have-SUBJ2SG otherwise misfortune-POSS2 give.FUT/COND1PL.

haskac'ar. understand-AOR2sG

If you find any rags or stuff to snatch, you put it in the communal pot. If you get caught (aor), don't sell out (prohibitive) your friends, don’t deal (subj) with snitches, or you'll get got. Understood? (V. Teveklian, Granite Doesn't Melt)

Tenses that are typically employed for actualized assertions, such as the present example (35), ${ }^{32}$ lend the aorist a gnomic meaning:

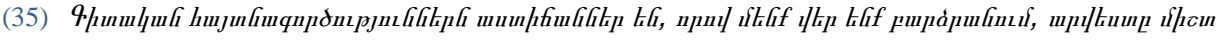

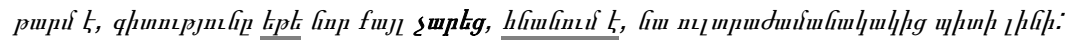

Gitakan haytararutyun-ner-n astijan-ner en, orov menk ver Scientific communication-PL-art degree-PL be.3PL, what-INST 1PL high enk.barjranum, arvest-ə mišt tàrm $\hat{e}, \quad$ gitut’yun-ə et $e$ climb.PST.1PL art-DEF always fresh be.3sG science-DEF if nor k’ayl č-ar-ec’, hnanum.ê, na ultražamanakakic piti.lini. new not NEG-do-AOR3SG be.aware.PST3SG 3SG supermodern be.FUT/OBL.3SG

Scientific papers are steps by which we rise; art always has a freshness (to it), [but] science, if [at any point] it doesn't progress (aor), beware, it must always be at the forefront. (Azg Daily, 26.03.2005)

Despite the negation, the verb here is strongly eventive, since the lack of any "new move" is considered a fatal mistake, that has consequences (which is translated by 'if ever'), echoed by the use of the obligative future (with piti) in the next clause.

Sentences where protasis and apodosis both use the aorist are also possible, especially when the sentence sounds like a threat:

32 We have not found examples of the apodosis in the perfect, in fact, the meaning of the conditional changes with the perfect. That would produce the meaning 'given that he has given the shirt, (obviously) he has changed', and the aorist would return to its value of past. (The hypothetical conjunction changes from the meaning of 'if' to that of 'given that/since'). 


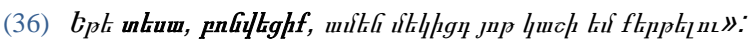

Et’e tesa, bŕnvec'-ik’, amen.mek-ic`-d yot` kaši em.k`ert’elu If see-AOR1sG be.catch-AOR2PL each-ABL-POSS2 seven leather whip.FUT1SG

If ever I see you, you get caught, each one of you will get seven lashes.

(S. Vartanyan, The Distant Days)

As we have said before, this syntactic pattern where the aorist has a hypothetical meaning allows various conjunctions, but also parataxis:

(37) 4q Guши

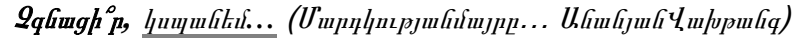

Kgn-as Aram-in kpatm-es inč or čišt $\hat{e}$,

Go.FUT/COND.2SG Aram-DAT tell.FUT/COND.3SG what that correct cop.PST.3sG,

khangstac'nes, es êl khamozem, or ner-i reassure.FUT.COND-2SG me also convince.FUT/COND-1SG that forgive.SUBJ-3SG

anpativ gorc-er-i-d. $\quad \check{C}^{\prime}$ gnac ${ }^{-i r}, \quad \underline{\text { kspan-em }}$ outrageous work-PL-DAT-2SG. NEG-go-AOR2sG, kill.FUT/COND-1sG

You will go tell Aram whatever it takes, you will reassure him, and I shall try to convince him to forgive your outrageous behavior. (If) you do not, I'll kill you. (V. Ananyan, I ... the mother of mankind)

It is also possible, as shown in example (31), to have a collocation that can be analyzed as a serial construction. Here, the first verb has lost its verbal autonomy and cannot be considered as a protasis. It forms, together with mek el 'suddenly', a collocation that is often followed by an hypothetical aorist.

- The distribution of aorist and subjunctive in hypothetical constructions

In all examples like (29) and (32) to (35), the aorist in the protasis can be replaced by a subjunctive, without affecting grammatical acceptability or the general meaning of the sentence. The corpus shows many numerous examples of hypothetical sentences with a subjunctive in the apodosis:

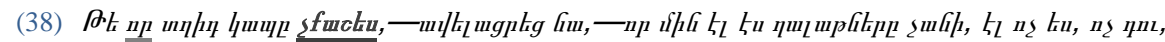

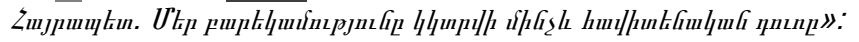

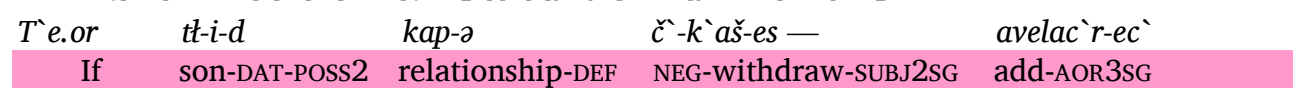
na-or $\min \hat{e} l \quad \hat{e} s \quad$ talat'-ner-a $\breve{c}$-an-i,

3SG that once again DEM manner-PL-DEF NEG-do-SUBJ3SG

\begin{tabular}{|c|c|c|c|c|c|c|}
\hline$\hat{e} l$ & $o \check{c}$ & es, & $o \check{c}$ & Hayrapet. & Mer & barekamut'yun-ə \\
\hline more & not & $1 \mathrm{SG}$ & not & 2sG, Hayrapet & our & friendship-DEF \\
\hline$k k t r v-i$ & & & minče & havitenakan & $d u \dot{r}-\partial$ & \\
\hline be.cut & UT /C & ND3SG & until & eternal & door- & \\
\hline
\end{tabular}

If you don't crack down (subj) on your son so that he definitively stops to behave this way then there will be no more me and you, Hayrapet. Our friendship will be finished for all eternity. (A. Movsisyan, A Minas, 1885)

The quasi-synonymy between aorist and subjunctive in such constructions is confirmed by example (39), drawn from an oral corpus where aorist and subjunctive are sequenced in an enumeration: 


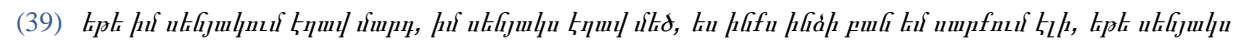

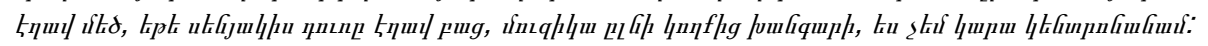

Et'e im senyak-umêt-av mard, im senyak'-s êt-av

If POSS1SG room-LOC be-AOR3SG person, POSS1SG room-POSs1 be-AOR3SG

\begin{tabular}{|c|c|c|c|c|c|c|c|c|}
\hline mec, & es & ink`s & inji & ban & em.sark`-um & êli, & et'e & senyak's \\
\hline big, & $1 \mathrm{SG}$ & emph & 1SG.DAT & thing & create.PST1SG & DISC, & if & room-POss1 \\
\hline
\end{tabular}

êt-av mec, et'e senyakis duŕ-a êt-av bac', muzika be-AOR3SG big, if room-GEN-POSS1 door-DEF be-AOR3SG open, Music

aln-i kotk'-ic xangar-i, es $\check{c}^{\prime}$-em.kara kentronanam.

be-SUBJ3SG side-ABL disturb-SUBJ3SG, 1SG NEG-power.1SG concentrate-SUBJ1SG

If I turned out, that there was someone in my room, that my room was [too] big, well, I would get worked up, if the room was too large, if the bedroom door was open, the music next door bothered me (subj), I won't be able to concentrate. (oral corpus, OSD polylogue 128, 2006)

However, by contrast with the subjunctive, the aorist emphasizes the subjectivity of the speaker, as shown by the nuances of suddenness in example (34), of warning or even threat in example (37), and of what can be translated by 'if ever', as opposed to 'if', more suitable for the sentences with a subjunctive in the protasis. In example (34), the hypothetical sentence with an aorist comes after a first hypothetical sentence with a subjunctive ('If you find any rags or stuff to snatch, you put it in the shared pot'), and the aorist appears exactly when the sentence takes on a flavor of threat ('if you get caught, you don't become a rat'). This sense is also congruent with the sense of 'arising' mentioned above: in example (39) senyake etav mets 'the room was (AOR) [too] big' cannot be interpreted as a stative predication of property, as with the present tense, but is rather recategorized as an achievement by the aorist. The room turned out to be too big, because the speaker became subjectively conscious of this property.

As we have seen, this kind of use of the aorist confirms the core features defined above for the aorist in discourse.

- Parameters that determine the "future" meaning of sentences

The specific meaning of these sentences is not determined by the syntactic structure in which they occur, since one can find in the corpus many examples that are syntactically similar to the previous ones, but where the aorist conveys a meaning of actualized accomplished past. 


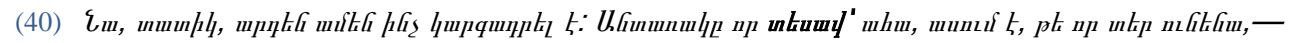

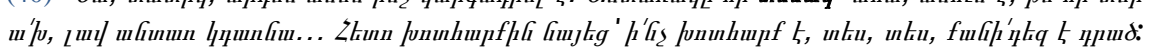
$\mathrm{Na}$, tatik, arden amen inč kargadrel.ê. Antaŕak-ə or tes-av, He, grandma, already all what arrange.PFT3sG. small.wood that see-AOR3sG, aha, asum.ê, tee or ter un-ena, akh!, lav antaŕ oh, say.PST1SG, that if master have-SUBJ3SG, ah good forest

kdarn-a. Heto xothark'-i-n nay-ec', become-FUT/COND.3SG Then hay-DAT-DEF look-AOR3SG tes, tes, k’ani dez ê.drac. look.imp look.imp how.many stacks placed.PFT3sG.

- He, grandmother, has already settled everything (pft). As soon as he saw the little wood, now he says that if someone cares for it, oh, it will become a beautiful forest. And he looked at the hay, what hay, look, how many stacks are there! (translation of Saltykov Schedrin)

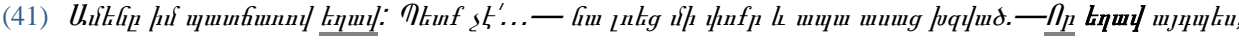

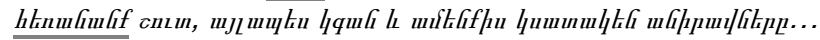

Amenə im patčaŕ-ov et-av. Petǩ.če... -na lŕr-ec All 1SG-GEN cause-INST be-AOR3SG. NEG.must.3SG... 3SG be.quiet-AOR3SG mi.p`ok'r ev apa as-ac' xzvac. a.bit and then say-AOR3sG defeated

- Or et-av aydpes, heranank` šut, aylapes

that be-AOR3sG thus, move.away-SUBJ1PL quickly, otherwise

kga-n ev amenk'-i-s ksatak-en anirav-ner-o come.FUT/CONG-3PL and all-DAT-1PL kill.COND-3PL unfair-PL-DEF

“All this happened (AOR.) by my fault. We musn’t!” He paused for a moment and then said, [sounding] defeated, "because this has happened, quickly move away, Eghiayi) otherwise they will come and kill us all, the unjust ones.” (Stepan Zorian,

We have seen that the tense of the verb in the protasis is not the determining factor, since in hypothetical sentences there are cases with the present (see 40) as well as the aorist (as in 41).

Neither is the conjunction a determining factor: et 'e 'if' has a hypothetical meaning, but we have seen that it can also mean 'since', that is, act as though an event has really been actualized, validating the propositional content of the apodosis. This causes the aorist in the protasis to refer to a validated past event. Conjunctions descending from temporal markers as henc' or 'as soon as', having an affinity with the past, can also occur with a hypothetical meaning where the aorist refers to a non-validated event.

In fact, what disables the past meaning of the aorist in "future clauses" is in most cases the prospective meaning of the preceeding context, marked:

- by a future or conditional/future verb (by contrast with (40) and (41) where this context explicitely refers to the past): 
(42) Fugupám

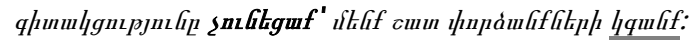

Bac`arjakapes inj hamar $\breve{c}-\hat{e}$, inč or anelu.ek', definitely 1SG.DAT for neg.COP.PST.3SG what that do.FUT2PL,

jer erexa-ner-i hamar ek'anelu. Et’e ays gitakc'utyun-ə 2PLGEN child-PL-DAT for do.FUT2PL If DEM consciousness-DEF

čunec'-ak` menk` šat p’orjank`-ner-i kg-ank`

NEG.be-AOR2PL 1PL much disaster-PL-DAT come.FUT.COND-1PL

It's definitely not for me, what you will do is for your children. If you are not aware of that, we are headed for great disasters. (Aravot Daily, 29.05.2008)

- by an adverb with future meaning:

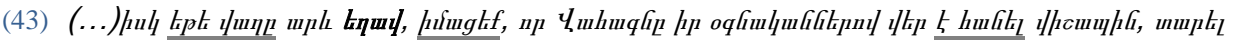
mplip innu:

isk et'e vała arev et-av, imac'ek' or Vahagn-ə And if tomorrow sun be-AOR3SG, know-IMP2PL that Vahagn-DEF

ir ognakan-ner-ov ver.e.hanel višap-i-n, tarel arevi mot. 3SG.GEN help-PL-INST mounted.PFT dragon-DAT-DEF brought sun-DAT toward.

And if the sun rises tomorrow, know that Vahagn will have mounted (pft) the dragon, will have led it toward the sun. (K. Movsisyan, 12 Journeys to the Depths of the Centuries)

- or by any other element with prospective meaning in the preceding context, like an injunction, an imperative verb as in example (31), or even a verb meaning 'to hope' as in example (44):

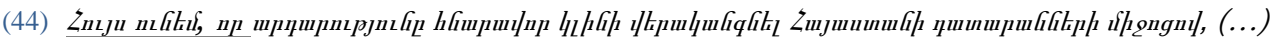

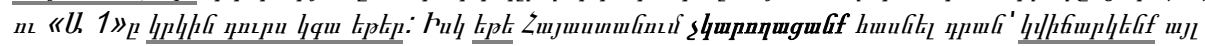
munjulifitipmus:

(Huys un-em or ardarut yun hnaravor klini verakangnel Hayastani dataranneri mijoc'ov u A1-ə krkin durs kga et'er.)

Isk et’e Hayastan-um $\check{c}$-karołac'ank` hasnel dran, And if Armenia-LOC NEG-be.able.to.AOR-1PL reach that.DAT

kvičark-enk ayl atyan-ner-um

argue.FUT.COND-1PL other court-PL-LOC

(I hope it will be possible to restore justice through the courts of Armenia, and that A1 will get back on the airwaves) But if we do not succeed inside Armenia, we will argue in front of other courts. (Aravot Daily, 22.05.2002)

- Preliminary conclusion: modal and assertive definition of "future" uses of the aorist

As we have seen, the future meaning of the aorist turns out to be rather a modal, hypothetical or potential meaning. In this sense, we agree with Lessan-Pezechki's labels. Actually, it is the temporal or modal context that disables the past value of the aorist, keeping activated only the aspectual meaning of a compact event together with the non-actualized assertion. In fact, we have seen that all aspectual properties that we pointed out for other uses of the aorist (compact event, eventually recategorized into an 
achievement, with a modal meaning of unexpectedness that can be produced in discourse) are also present in these "future" uses.

For this reason, it seems inappropriate to claim that the future is one of the meanings of the aorist. This meaning is contextually conditioned in several hypothetical sentences where the core value of the aorist, the disjunction from $\mathrm{T}_{0}$, foregrounds the aspectual meaning of the aorist, making its temporal meaning covert. Such an analysis allows us to consider together the gnomic and hypothetical meanings of the aorist, as in both cases the situation of utterance is suspended and enunciative coordinates are not activated.

The difference between gnomic and hypothetical meanings pertains to the anchoring into the situation of utterance. In hypothetical uses, protasis is not actualized, and thus there is disjunction from $\mathrm{T}_{0}$, but enunciative coordinates (especially $\mathrm{S}_{1}$ ) are activated, which allows subjective meanings like unexpectedness or threat. By contrast, the gnomic aorist implies that enunciative coordinates are not activated: the truth-value of the sentence is not temporally specified, there is no possiblity to refer to the first and second person, and thus there can be no subjective meaning, like surprise or unexpectedness.

In both cases the aorist event is not asserted in the sense assertion was defined at the end of section 1 . In the protasis, it builds a framework that conditions the actualization of the apodosis. The protasis may either 1) express a hypothesis that can become true in the future (hypothetically), which will involve the actualization of the apodosis, or 2) select a class of occurrences that condition the general truth-value of the apodosis. In fact, what is actualized in these sentences is the correlation between the protasis and the apodosis.

These kinds of uses, in contrast to the others described above, are restricted to Eastern Armenian and are not represented in Western Armenian, where such sentences would be realized with a subjunctive instead of an aorist.

\section{General conclusion: invariant and contextual meanings of the aorist in Armenian}

In this paper, we have attempted to demonstrate that the Armenian aorist can be defined by three invariant features from which all the attested meanings 
can be predicted, as resulting from the combination of these invariants with different contextual and enunciative parameters. The high level of abstraction of these invariants, in contrast to the referential constraints given by many grammarians, allows us to account for a wide range of meanings, while avoiding too-literal generalizations and the counter-examples they generate. Moreover, we showed in section 1. that these invariant features are connected to morphological properties of the aorist in Armenian.

\section{a. Types of assertive anchoring}

These three features, eventiveness, compacity and lack of anchoring to $T_{0}$, manifest themselves differently, depending on the assertive type of the sentence. We have distinguished three types: the narrative register and the discourse register in simple assertive sentences, and a specific type for the protasis of the hypothetical complex sentence.

1) In the narrative register, the temporal anchoring of the event is disjuncted from $\mathrm{T}_{0}$, which is consistent with the invariants of the aorist: the event is disconnected from the situation of utterance, the temporal anchoring is textinternal, operationalized by circumstantial markers and/or chronological sequence of several events. The aorist event refers to a past event without specific modal meaning.

2) In the discourse register, which implies an anchoring to the situation of utterance, the anchoring of the aorist event is not granted by the aorist, but rather the assertion is actualized in relation to the situation of utterance. In case of discrepancy between the temporal anchoring of the aorist (as determined by its morphology) and that of the register, modal meanings arise, depending on the semantic type of the verb (internal state, achievement of a natural process, etc.). The common features of these meanings are:

- Aspectually speaking, the feature of advent (related to the compacity, and linked to the phasal meanings of inchoation, change of state, achievement or snapshot).

- Modally speaking, an ensuing strong assertion, possibly exclamative or argumentative, sudden awareness or qualitative salience, which can be related to some mirative meanings.

3) In discursive hypothetical sentences, the aorist appears essentially in the protasis, which is not fully assertive (what is asserted is not the truth value of the propositional content), and the event is referred to as a hypothetical framework that can actualize the event of the apodosis. These sentences can be of two semantic types: 
- The prospective hypothesis of the advent of an event ('if ever'), with various subjective shades (detrimental, mirative, of threat, etc.), where the eventuality of the aorist event is considered in a specific situation that could happen, or not, in the future.

- The generic hypothesis of a class of situations that allow the assertion of a gnomic truth, non-specific, related to any occurrence of this class.

\section{b. The defining invariants of the aorist}

Thus, in these three registers, the defining invariants of the aorist manifest themselves depending on the enunciative parameters of the register, and in each case the aorist is distributionally in contrast with two different tenses:

1) Temporal anchoring: the aorist is a past tense disjuncted from $T_{0}$. It contrasts a) with the perfect (with which it shares the feature of past accomplished tense), and b) with the subjunctive, which is congruent with formal affinities shown in Table 2.

The aorist is event-oriented, since the perfect's target is the relevance of the event for the moment of the utterance. Thus the aorist is a narrative tense, since the perfect implies a situation of utterance. ${ }^{33}$

In discourse contexts, the orientation toward the event leads up to an emphatic assertion, focused on the advent of the event, with several associated nuances: strong assertion (19), argumentative, (20) and (21), and eventually exclamative nuance, (22) to (23).

In contexts where the actualization of the event is not granted (hypothesis), thas is, where there is no possibility of temporal anchoring, the aorist may appear without temporal meaning instead of a subjunctive. By contrast with the subjunctive, the aspectual meaning of the aorist is conserved, giving the sentence a meaning of "advent", that is vested in by various subjective meanings (detrimental, of threat, mirative; in contexts of strong threat, the apodosis can also be expressed with the aorist, as in example (36)).

2) Compacity/globalness and dynamic/eventive feature: the aorist is telic, in that it contrasts with the resultative perfect, which recategorizes the event into a state. This explains the anchoring of multiple events one to another in narrations. Compacity does not allow to break down events into phases, framing each one as a single phase, that is, processing the whole event as an achievement, in Vendler's sense, see example (7). Thus, the aorist is able to affect the lexical semantics of verbs, by operating what we call a re-

33 The use of the perfect in the narrative creates a referential situation, as shown in the example discussed in footnote 17. 
categorization. Durative, non-telic, or even stative or existential verbs (examples (6), (39)), may be "recategorized" by the aorist as non-durative, telic, eventive, either by adding aspectual meanings like the inchoative (examples (21) to (24)) or the snapshot effect, as in the aorist of anticipation (25), or by adding modal meanings, as teleology (examples (26) and (27)) or qualitative or notional saliency with focus on the intentionality in example (28).

\section{c. Morphological properties of the aorist in the verbal system of Modern Armenian}

Finally, we demonstrated how each of the particular meanings we have accounted for can be explained by a combination between the invariants and the properties of each of the enunciative anchorings, the invariants being related to the morphological properties of the aorist:

- Perfective (stem) (shared with the perfect and its variants).

- Past (inflection) (shared with all the tenses exhibiting a temporal correlative pair, see Table 1).

- No strategy for explicit marking of the actualization (see Table 3) (shared with the subjunctive)

- Not a member of a correlative temporal pair (shared with the imperative)

These formal properties converge and confirm semantic properties and contrasts already brought to light.

\section{d. Cross-linguistic constants and specificities}

We saw that invariants described here for the Armenian aorist, which encounter constants introduced by Culioli in the definition of the " aoristique ", also match the description of the aorist in several IndoEuropean laguages mentioned here. Obviously, the shape of the aorist is not exactly the same in all the languages concerned, nor even in EMA and WMA, since the latter does not exhibit aorist in prospective protasis. There can be several explanations for this, and they are not mutually exclusive.

- Some of the occurrences are a kind of collocation (as the serial construction in example (31), but also popular expressions with kspanem 'I kill (you)', as in example (37), very usual in colloquial EMA). In fact, even if the use of the aorist in hypothetical clauses is not characteristic of WMA, its meaning 
remains interpretable for a speaker of WMA. ${ }^{34}$ Areal phenomena may also play a role in these differences: in Turkish, a contact language for WMA, there is no parallel to the hypothetical aorist. By contrast, in the Iranian area, where EMA evolved, there is one.

- The organization of the verbal system of each language, namely the inventory of tenses, is determinant for their distinctive features. Between EMA and WMA, as well as in some of the languages mentioned above, the existence or the lack of a specialized tense for mirative or evidential functions plays an important role in the definition of the modal meanings that the aorist can carry. For example, in Modern Greek, the lack of an evidential or mirative tense explains why the aorist carries the corresponding meanings (22-23). By contrast, in WMA, where there is a dedicated evidential tense, the modal meanings of the aorist are narrower than in MEA, since the meanings of strong assertion, notional saliency, argumentation and exclamation are carried by the evidential tense in WMA (cf. Bonnot \& Donabedian 1999; Donabedian 1996, 2001, 2012). Similarly, in the verbal system of Hindi, mirative meanings are carried by the aorist.

These points confirm the need to consider formal properties and contrast between tenses in the system when defining the aorist's specific shape in a given language. In fact, the way the core values defined here assume temporal, aspectual and modal meanings depends on the enunciative parameters, on the context, but also on the contrast with other available tenses in a given system.

\section{References}

Abeghian, Manuk. 1965. Lujng lkqu/h untunıpjnıli [Theory of Armenian Language]. Erevan : Melkonyan Fond.

Barchian, Anaït. 2002. Doit-on considérer la différence entre le passé simple et passé composé comme une différence aspectuelle? Proceedings of the 6th International Conference on Armenian Linguistics, Anaïd Donabédian \& Agnès. Ouzounian, (eds.). Slovo 24-25/2001-2002: 299-309. Paris: INALCO.

Bonnot, C., and Donabédian, Anaïd. 1999. Lorsque la morphosyntaxe rencontre la prosodie: accent non final en russe et médiatif en arménien. Faits de Langues 10/1999: 182-190

Cohen, David. 1985. L'aspect verbal. Paris: PUF.

34 The aorist can be found in aphorisms in Western Armenian, but there is a tendancy for it to be supplanted by the evidential in these uses. 
Culioli, Antoine. 1980. Valeurs aspectuelles et opérations énonciatives: l'aoristique. In La notion d'aspect, J. David \& Robert Martin (dirs), 182193. Vincennes: Recherches linguistiques.

- 1990. Pour une linguistique de l'énonciation. Paris: Ophrys.

Dahl, Östen. 1985. Tense and Aspect Systems. Oxford: Blackwell.

Donabédian, Anaïd. 1996. Pour une interprétation des différentes valeurs du médiatif en arménien occidental. In L'énonciation Médiatisée, Zlatka Guentcheva (ed.): 87-108. Louvain: Peeters, Bibliothèque de l'Information grammaticale.

- 1998. Mode d'expression de l'accompli et aspectualité en arménien occidental. Actances 9: 13-32. Paris: Rivaldi.

- 2001. Toward a Semasiological account of Evidentials: an Enunciative Approach of -er in Modern Western Armenian. Journal of Pragmatics 33/3: 421-442.

- 2012. Evidentiel et progressif : quel statut grammatical pour la saillance prédictive ? Saillance, Faits de Langues 39/2012: 65-82.

Dum-Tragut. 2009. Armenian (Modern Eastern Armenian), Amsterdam/ Philadelphia: John-Benjamins.

Giorgi, Alessandra, Harutyunian Sona. 2011. Remarks on Temporal Anchoring: The case of the Armenian aorist. Working Papers in Linguistics, vol. 21/2011: 83-105.

Guentcheva, Zlatka. 1990. Temps et aspect, l'exemple du bulgare contemporain. Paris : CNRS Editions.

Lazard, Gilbert. 1957. Grammaire du persan contemporain. Paris: Klincksiek.

Lessan-Pezechki, Homa. 1998. L'aoriste persan. In La conception métagrammienne du temps verbal/Le langage et l'Homme vol. XXXIII, 23, Michel Maillard (ed.). Louvain: Peeters.

2002. Système verbal et Deixis en persan et en français, Paris: L'Harmattan.

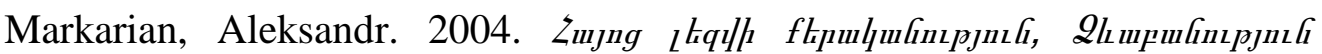
[Grammar of Armenian, Morphology]. Yerevan State University Press.

Maslov, Juri. 1981. Грамматика болгарского языка [Grammar of Bulgarian], Moscou : Vysšaya škola.

Montaut, Annie. 2006a. Mirative Meanings as Extensions of Aorist in Hindi/Urdu. In The Yearbook of South Asian Languages and linguistics, R. Singh (ed.), 49-70. 
— 2006b. Figures du sujet énonciateur: deux cas particuliers du discontinu et du continu en hindi/ourdou. In Actes du colloque de Cerisy "Antoine Culioli, un homme dans le langage”, D. Ducard \& C. Normand (eds), 187-208. Paris: Ophrys.

Plungian, Vladimir. 2006. К описанию армянской глагольной парадигмы: "темпоральная подвижность" и перфектив // Армянский гуманитарный вестник (Ереван), [Contribution to the description of the armenian verbal paradigm: "temporal mobility" and the perfective // Armjanskij gumanitarnyj vestnik (Erevan)]. No. 1, 7-20.

Robert, Stéphane. 1996. Aspect zéro et dépendance situationnelle: l'exemple du wolof. In Claude Müller (éd), Dépendance et intégration syntaxique (subordination, coordination, connexion) [Linguistische Arbeiten $n^{\circ} 351$ ]. Tübingen: Niemeyer, 153-161.

Sauvageot, Serge. 1965. Description synchronique d'un dialecte wolof: le parler du Dyolof. Dakar: IFAN.

Vassilaki, Sophie \& Tsamadou-Jacoberger, Irène. 1995. Aspects du grec moderne. Lallies 15, 7-69. Paris: Presses de l'ENS.

Vogüé, Sarah de. 1989. Littérature et linguistique : la catégorie de l'histoire. Semen 4. <http://semen.revues.org/6713> (2 march 2013)

- 1995. L'Effet aoristique. In Langues et langages. Problèmes et raisonnement en linguistique, J. Bouscaren, J.J. Frankel \& S. Robert, 247259. Paris: PUF. 